\title{
Tanzanian mushrooms and their uses 6. Lactarius
}

\author{
PÄIVI KARHULA, MARJA HÄRKÖNEN, TIINA SAARIMÄKI, ANNEMIEKE VERBEKEN and \\ LEONARD MWASUMBI
}

KARHULA, P., HÄRKÖNEN, M., SAARIMÄKI, T., VERBEKEN, A. \& MWASUMBI, L. 1998: Tanzanian mushrooms and their uses 6. Lactarius. - Karstenia 38:4968. Helsinki. ISSN 0453-3402

Seventy-two specimens of Lactarius were collected in Tanzania between 1990-1995. The material contained 27 species of which 15 had not been described. Two of these, Lactarius denigricans Verbeken \& Karhula and L. densifolius Verbeken \& Karhula have been described since then and three more species, L. xerampelinus Karhula \& Verbeken, L. tanzanicus Karhula \& Verbeken and L. volemoides Karhula are described here. In addition, all the identified species of Lactarius in Tanzania are listed and annotated. Many Lactarius species are considered edible in Tanzania although there are a range of opinions among the different tribes some of which are contradictory.

Key words: Africa, Agaricales, Lactarius, Tanzania, taxonomy.

Päivi Karhula, Marja Härkönen and Tïna Saarimäki, Department of Ecology and Systematics, P.O. Box 7, FIN-00014 University of Helsinki, Finland

Annemieke Verbeken, Vakgroep Morfologie, Systematiek en Ecologie, Laboratorium Plantkunde, K.L. Ledeganckstraat 35, B-9000 Gent, Belgium

Leonard Mwasumbi, Department of Botany, University of Dar es Salaam, P.O. Box 35060, Dar es Salaam, Tanzania

\section{Introduction}

This article is a part of a series of studies dealing with Tanzanian edible mushrooms. For the background, methods (collecting and interviews), research area of the project and habitats see Härkönen et al. (1993a). The first results on Russula, Coprinus, Amanita, Termitomyces and Gasteromycetes species were published in Härkönen et al. (1993a-b, 1994b), Saarimäki et al. (1994), Härkönen (1995), Calonge et al. (1997) and about edible and poisonous species in general in Härkönen et al. (1994a, 1995).

Until recently (Verbeken 1995a-1996d) Lactarius has been poorly studied and collected in tropical East Africa. Lactarius species are, however, frequently found in the open Brachystegia woodland (miombo) of Southern and Western Tanzania. Apart from the Tanzanian collections studied here and gathered by Härkönen, Karhula and Saarimäki between 1990 and 1995, many Lactarius have also been collected between 1991 and 1996 from the neighbouring miombo woodlands of Burundi, Malawi and Zambia, principally by Buyck (priv. herb.) but also by Piearce and Morris. For the present state of knowledge concerning Lactarius in the neighbouring countries, we refer to Verbeken (1995a-1996d) and Buyck \& Verbeken (1995) and Buyck (1994).

As far as Tanzania is concerned, the only published records of Lactarius species concern $L$. gymnocarpus (Pegler 1977), L. pseudogymnocarpus (Verbeken 1995b), L. chromospermus (Munyanziza 1994), L. kabansus (Härkönen et al. 
1995), L. edulis (Härkönen et al. 1995), L. aff. phlebophyllus sensu Härkönen et al. (1994a, $1995=$ L. xerampelinus Karhula \& Verbeken sp. nov.) and $L$. aff. pseudovolemus sensu Härkönen et al. $(1994 \mathrm{a}, 1995=$ L. volemoides Karhula sp. nov.).

\section{Material and methods}

The authors collected 72 Lactarius specimens during their five collecting trips 1990-1995. All the specimens are deposited at the Botanical Museum of the University of Helsinki $(\mathrm{H})$ and some representative specimens in the herbario of Gent (GENT) and Dar es Salaam (DSM). All the collection numbers concern the specimens gathered by us (Saarimäki et al.) if not mentioned otherwise. Härkönen and Saarimäki collected and photographed the specimens, wrote the field notes and interviewed the local people. The microscopical details were studied and drawn by Karhula except for some spore ornamentations that were drawn by Verbeken (Figs. 3 and 16).

The spore ornamentation is described and illustrated as observed in Melzer's reagent. Line-drawings of the spores were made with a Leitz microscope and a camera lucida at $\times 6700$ magnification. Spores were measured in side view in Melzer's reagent, excluding the ornamentation. Measures are given as lowest - average - highest value for length and width. Q stands for length / width ratio. Measurements were made with the aid of a measuring-ocular connected with a Leitz microscope. Other microscopic structures were studied in Cotton Blue. The structure of pileipellis, basidia and cystidia were drawn with the aid of a camera lucida at $\times 1000$ magnification. The terminology used for elements of lamellae is adopted from Buyck (1991), for the structure of pileipellis and stipitipellis from Verbeken (1996c).

\section{Tanzanian species of Lactarius}

Among the 72 specimens there were 27 species of Lactarius of which 15 species are most probably new to science. Two species; $L$. densifolius and $L$. denigricans, had been described earlier by Verbeken and Karhula, based on material from Tanzania and Burundi in Verbeken (1996a,b). In this contribution $L$. tanzanicus sp. nov., $L$. volemoides sp. nov. and $L$. xerampelinus $\mathrm{sp}$. nov. are described. Due to either lack of sufficient material or extensive macroscopical descriptions, the other species have not been described. All identified species are annotated, treated in systematic order (Verbeken 1996c) and illustrated.

\section{Lactarius luteopus Verbeken, Mycotaxon} 55:536. 1995. - Fig. 1

Vernacular names: Wunyamalagata (Bena-language); Unguyuu (Ndendeuli); Lai, Hajuli (Matengo).
Edibility: The information gathered is very variable. Some Bena people consider it inedible, some parboil and dry it before use. The Ndendeuli think it is delicious.

Ecology: Miombo woodland or degraded woodland with Uapaca, Brachystegia, Parinari, Ochna, Rothmannia, Combretum molle, Garcinia, Gardenia, Eriosema, Faurea, Bridelia and Protea.

Specimens examined: Tanzania. Southern Prov., Songea Distr., ca. $25 \mathrm{~km} \mathrm{~N}$ of Songea along the main road, ca. $5 \mathrm{~km}$ from the main road, Mawa village (10 $35 \mathrm{BC})$, 1000 m, 27.I.1993 1415, 1424; About $40 \mathrm{~km}$ N of Songea, Hanga, Nyamagoma village (10 35 BC), $990 \mathrm{~m}$, 27.I.1993 1432. Southern Highlands Prov., Njombe Distr., Ngaramiro, $2 \mathrm{~km} \mathrm{~N}$ of Kidugala (09 $34 \mathrm{BA}$ ), on hill slope, red soil, $1550 \mathrm{~m}, 31 . \mathrm{I} .1993$ 1486; Mbalali village $11 \mathrm{~km} \mathrm{~S}$ of Kidugala, red soil, 1650 m, 1.II.1993 1504.

Observations: L. luteopus, L. tanzanicus, $L$. medusae, L. gymnocarpoides, $L$. volemoides, $L$. pumilus and $L$. denigricans have a lampropalisade-like pileipellis (Fig. 4 and 8). L. luteopus is easy to recognize by the bright yellow fruit bodies. L. luteopus has been collected by Buyck from Zambia and was later described by Verbeken (1995b). The colour photograph in the present publication is the first one published of this species.

Lactarius tanzanicus Karhula \& Verbeken sp. nov. - Figs. 2-4

Pileus 6-13 cm diam., primo convexus tum sursum reflexo, pileipellis vivide aurantiaca, impolita. $\mathrm{La}$ mellae decurrentes, distantes, cremeae, maculis brunneis. Stipes $3-8 \mathrm{~cm}$ longus, $1.5-3 \mathrm{~cm}$ crassus, albidus vel cremeus, irregulariter brunnescens. Contextus albidus, gustu mitis, odore dilute piscis similis. Latex albidus. Sporae ellipsoideae, 6.97.3-8 × 5.0-5.4-6.3 $\mu \mathrm{m}$, incomplete reticulatae, verrucis parvis cristis paucisque ornatae, macula suprahilaris interdum distale amyloidea. Basidia 60-70 × 7-10 $\mu \mathrm{m}$, cylindrata ad clavata. Pleurocystidia vera absentia. Pileipellis bistrata, elementa suprapellis 20-110 5-10 $\mu \mathrm{m}$, clavata vel irregulariter cylindrata, saepe ramosa, pariete incrassato, subpellis pseudoparenchymata.

Holotype: Tanzania. Southern Prov., Kilwa Distr., Mavuji village, $78 \mathrm{~km}$ S of Kilwa Masoko, specimen purchased, 18.I.1993 Saarimäki et al. 1277 (H, isotypus DSM).

Pileus 6-13 cm in diameter, first convex then uplifted, margin wavy and uneven, pellis bright 


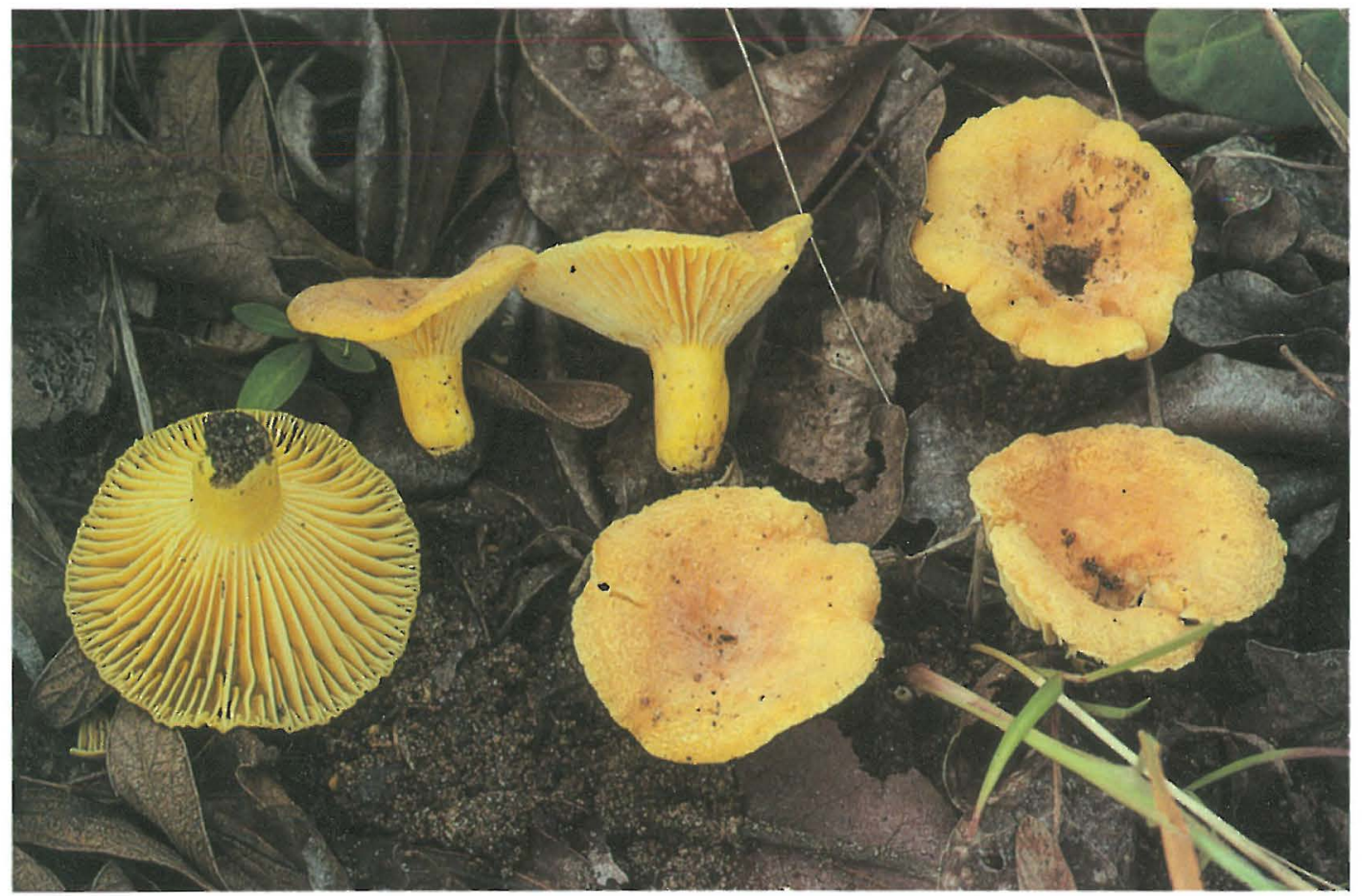

Fig. 1. Bright yellow fruit bodies of Lactarius luteopus (1432).

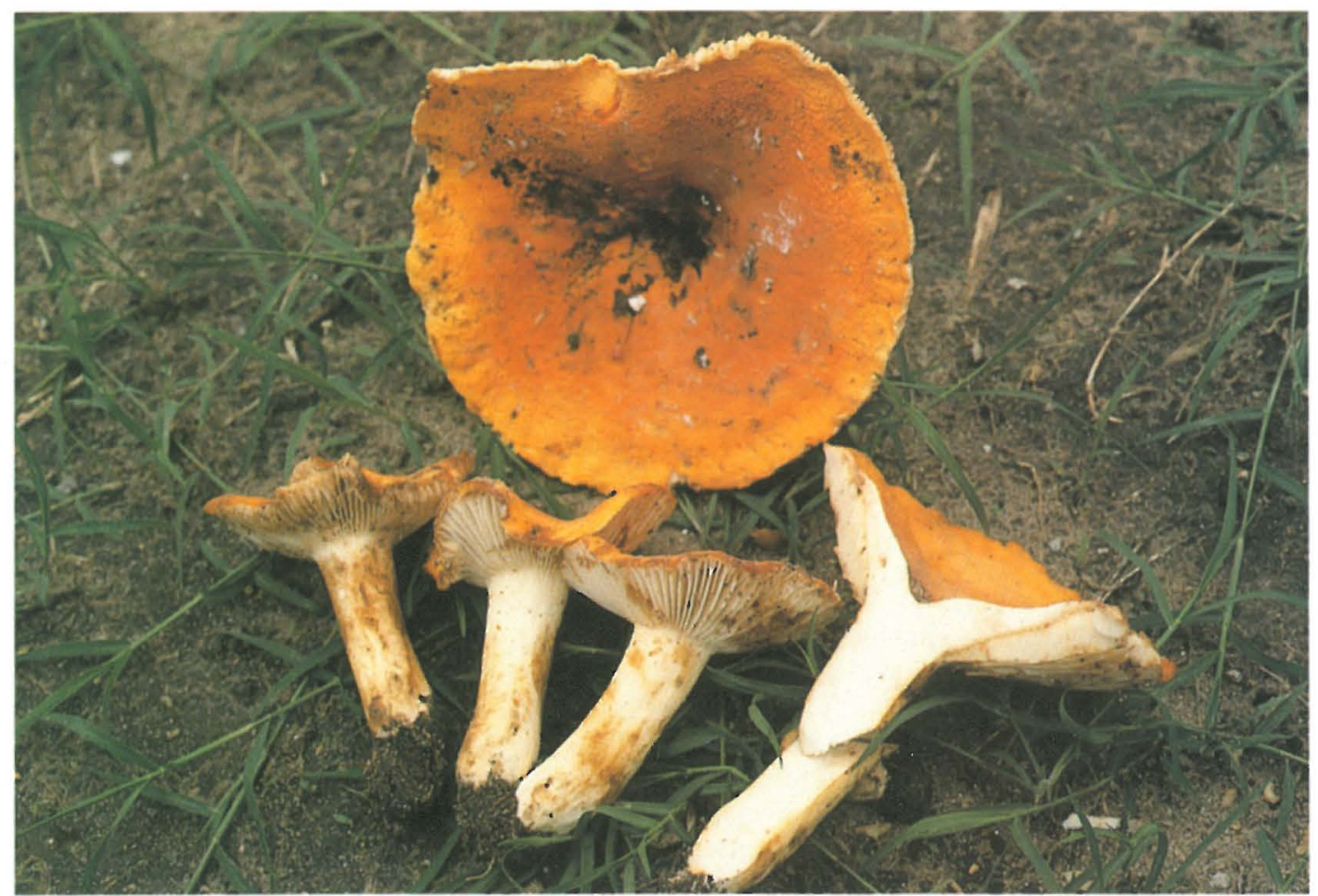

Fig. 2. Fruit bodies of Lactarius tanzanicus (holotype). 


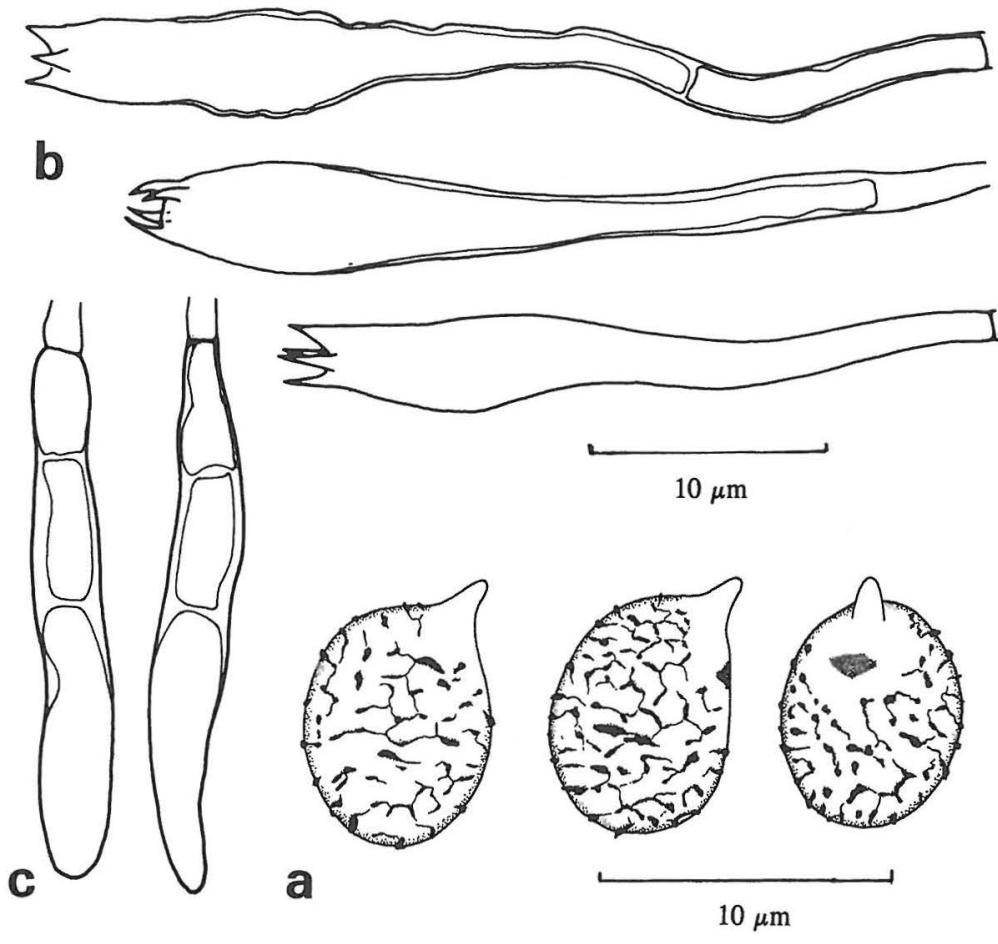

Fig. 3. Lactarius tanzanicus. - a) spores (holotype), b) basidia $(1115), \mathrm{c})$ marginal cells (holotype). orange, matted, slightly warted. Lamellae decurrent, distant, fairly thick, up to $7 \mathrm{~mm}$ broad, spaced with several lamellulae, cream with brown spots, lamella edge smooth. Stipe $3-8 \times 1,5-3 \mathrm{~cm}$, equal or slightly tapering, sometimes eccentric, striate, matted, white or cream, damaged areas turning brown, veil absent. Context in cap and stipe white, hard, brittle, milk latex white. Smell faint, fishy. Taste mild.

Spores ellipsoid, 6.9-7.3-8.0 × 5.0-5.4-6.3 $\mu \mathrm{m},(\mathrm{Q}=1.14-1.37-1.50 ; \mathrm{n}=60)$, ornamentation amyloid, very fine, with small warts and few fine connective lines, plage sometimes with distal amyloid area. Basidia 4-spored, 60-70 × 7-10 $\mu \mathrm{m}$, cylindric to clavate, often thick-walled at the base. True pleurocystidia absent. Pseudopleurocystidia not abundant, 3-5 $\mu \mathrm{m}$ in diameter, cylindric, obtuse. Lamella-edge sterile, marginal cells $45-53 \times 5-6 \mu \mathrm{m}$, cylindrical, rounded or sharp pointed, thick-walled at base and septate. Pileipellis a lampropalisade; elements of the suprapellis 20-120 ×5-10 $\mu \mathrm{m}$, clavate to irregularly cylindric, some narrowly cylindric, often branched, thick-walled (1-3 $\mu \mathrm{m})$, subpellis pseudoparenchymatous, cells rounded, 10-25 $\mu \mathrm{m}$ in diameter. Stipitipellis a lampropalisade; elements of the suprapellis $30-45 \times 8-10-(15) \mu \mathrm{m}$, broadly clavate to lanceolate and cylindric, thickwalled, subpellis pseudoparenchymatous.

Vernacular names: Imbohu nankuta (Makonde); Uyoga mchenga (Yao).

Edibility: The Makonde people consider it edible after parboiling, The Ngindo believe it is inedible.

Ecology: Acacia-Combretum woodland.

Additional specimens examined: Tanzania. Western Prov., Tabora Distr., ca. $20 \mathrm{~km}$ of Tabora, Lulanguru village (05 $32 \mathrm{BA}), 1100 \mathrm{~m}$, 14.XII.1991 1115 .

Observations: This species differs from L. gymnocarpus by its white or whitish stipe and clearly denser lamellae. The elements from the suprapellis of the pileipellis are less irregular and somewhat narrower (up to $10 \mu \mathrm{m}$ ) than those of L. gymnocarpus. Furthermore, the elements of the stipitipellis are up to $45 \mu \mathrm{m}$ long, whereas in L. gymnocarpus they may be $120 \mu \mathrm{m}$ long.

L. tanzanicus could be placed in the subgenus Lactifluus (Burl.) Hesler \& A.H. Sm., section Caperati R. Heim. 


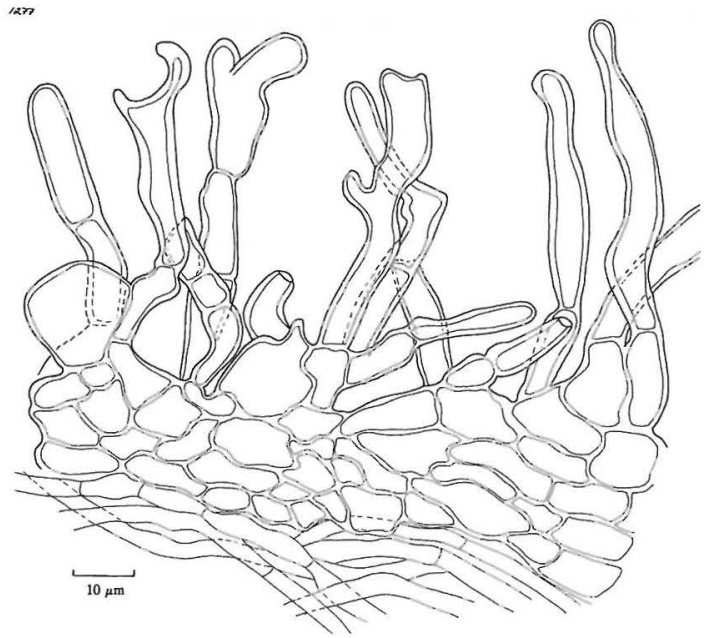

Fig. 4. The structure of pileipellis in Lactarius tanzanicus (holotype).

Härkönen et al.(1994a) described L. tanzanicus as L. gymnocarpus sensu lato in their article about the edible and poisonous mushrooms of Tanzania.

Lactarius gymnocarpoides Verbeken, Mycotaxon 55:530. 1995. - Fig. 5

Vernacular names: Witsiba, Wunyidziva (Bena). Edibility: These fungi have to be parboiled before cooking to avoid bitterness (Bena).

Ecology: Degraded Uapaca woodland, few Brachystegia, Garcinia, Eriosema, Ochna, Faurea, Bridelia and Protea.

Specimens examined: Tanzania. Southern Highlands Prov., Njombe Distr., Mbalali village $11 \mathrm{~km}$ S of Kidugala, red soil, $1650 \mathrm{~m}, 1 . \mathrm{II} .19931508$.

Observations: L. gymnocarpoides is very closely related to L. tanzanicus; both have lampropalisade-like pileipellis and very low ornamentated spores. However, L. gymnocarpoides has a lighter coloured pileus and stipe and clearly bigger spores than L. tanzanicus.

Lactarius volemoides Karhula sp. nov. - Figs. 6-8

Pileus 4.5-9 cm diam., convexus ad umbilicatus, margine incurvo tum ad sursum reflexo, pileipellis tomentosa, leviter rimosa, aurantiaca vel aurantiobrunnea. Lamellae decurrentes, distantes, al- bidae ad cremeae. Stipes 2-3 cm longus, $0.6-2 \mathrm{~cm}$ crassus, aurantiobrunneus, stipitipellis tomentosa. Contextus albus, gustu mitis, odore piscis similis. Latex abundans, albidus. Sporae ellipsoidae, 8.5-9.2-10.5 ×6.0-7.1-8.2 $\mu \mathrm{m}$, incomplete ad irregulariter reticulatae, verrucis sublaevibus interdum connexis ornatae; macula suprahilaris non amyloidea. Basidia 53-90 ×9.5-11 $\mu \mathrm{m}$, clavata. Pleurocystidia vera absentia. Pileipellis bistrata, elementa suprapellis 10-75 × 3-6 $\mu \mathrm{m}$, cylindrata, 2- vel 3-septata, pariete incrassato, subpellis pseudoparenchymata.

Holotype: Tanzania. Southern Highlands Prov., Mbeya Distr., Mbozi (09 32 BB), 1650 m, 24.III.1991 Saarimäki et al. 705 (H).

Pileus 4.5-9 cm in diameter, first convex, then umbilicate, margin incurved then uplifted. Pellis orange or orange-brown, darker at centre, tomentose, slightly wrinkled. Lamellae decurrent, distant, thick, up to $7 \mathrm{~mm}$ broad, white or cream, lamella-edge smooth, some forked near margin, few short lamellulae irregularly. Stipe $2-3 \times 0.6-2 \mathrm{~cm}$, tapering downwards, orange-brown, tomentose. Context white, brittle. Milk latex white and abundant. Smell weak, fishy (like L. volemus). Taste mild.

Spores 8.5-9.2-10.5 × 6.0-7.1-8.2 $\mu \mathrm{m},(\mathrm{Q}=$ $1.16-1.37-1.50, \mathrm{n}=60$ ) ellipsoid, ornamentation amyloid, composed of small warts and thin ridges forming an irregularly interconnected reticulum, plage inamyloid. Basidia 4-spored, 53-90 ×9.5$11 \mu \mathrm{m}$, clavate, thin-walled. Lamella-edge fertile. True pleurocystidia absent. Pseudopleurocystidia 5-7 $\mu \mathrm{m}$ in diameter. Subhymenium and hymenophoral trama composed of sphaerocytes, $12-15 \mu \mathrm{m}$ in diameter and lactifers, $6-10 \mu \mathrm{m}$ in diameter. Pileipellis a lampropalisade, elements of suprapellis 10-75×3-6 $\mu \mathrm{m}$, cylindrical, 2- or 3septate, thick-walled $(1-2 \mu \mathrm{m})$, subpellis pseudoparenchymatous, composed of rounded, thick-walled cells, $15-20 \mu \mathrm{m}$ in diameter. Stipitipellis consists of repent hyphae, the hyphal tips projecting outwards. Clamp connections absent. Vernacular names: Ufanyi, Wunyamagulu (Bena), Mpofu (Nyiha), Uselele, Utundulu (Safwa).

Edibility: Hunters may eat it as raw in the field. It is easy to preserve by drying in the sun.

Ecology: Miombo woodland planted with Cupressus or dominated by Uapaca, Brachystegia and Parinari. 


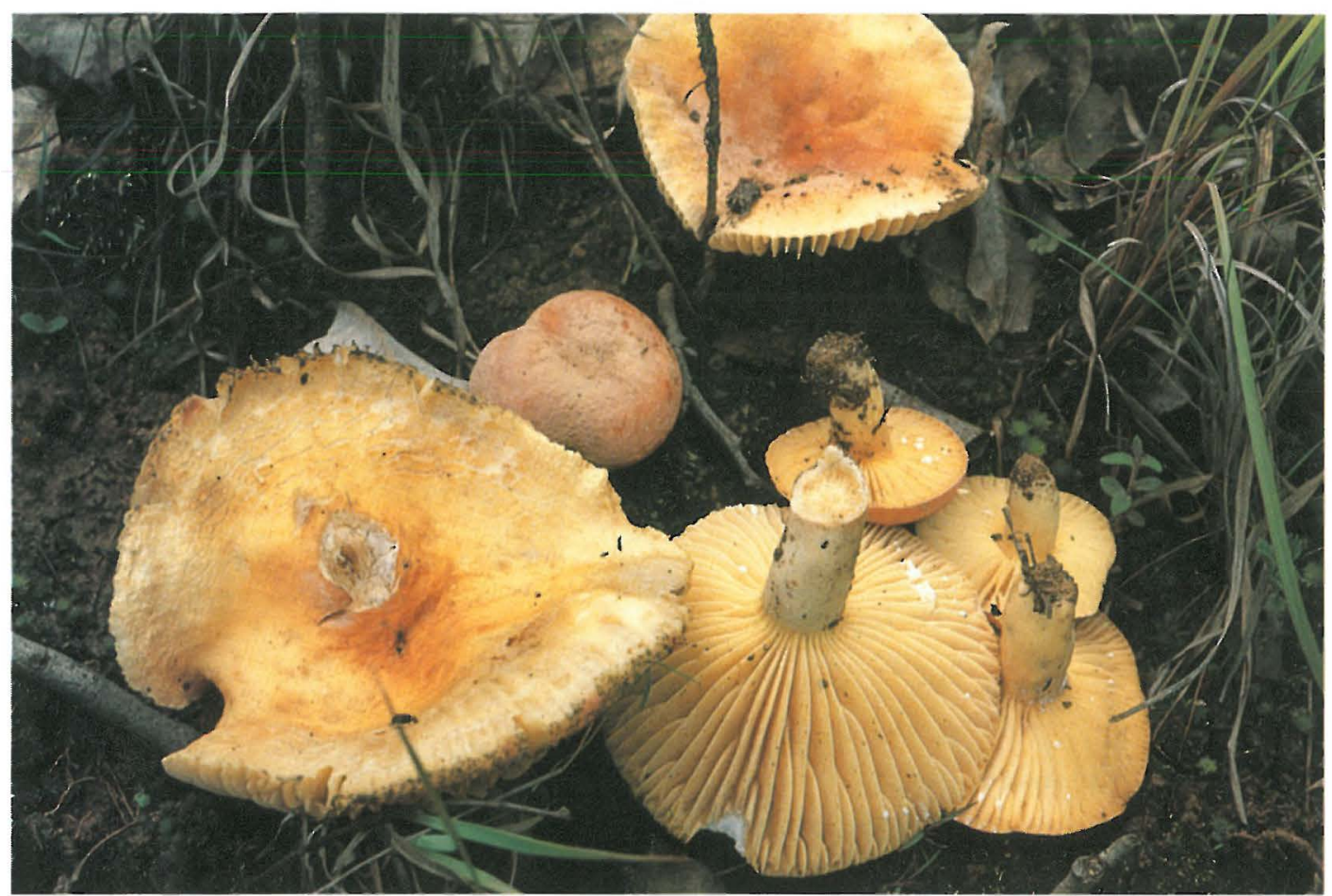

Fig. 5. Fruit bodies of Lactarius gymnocarpoides (1508).

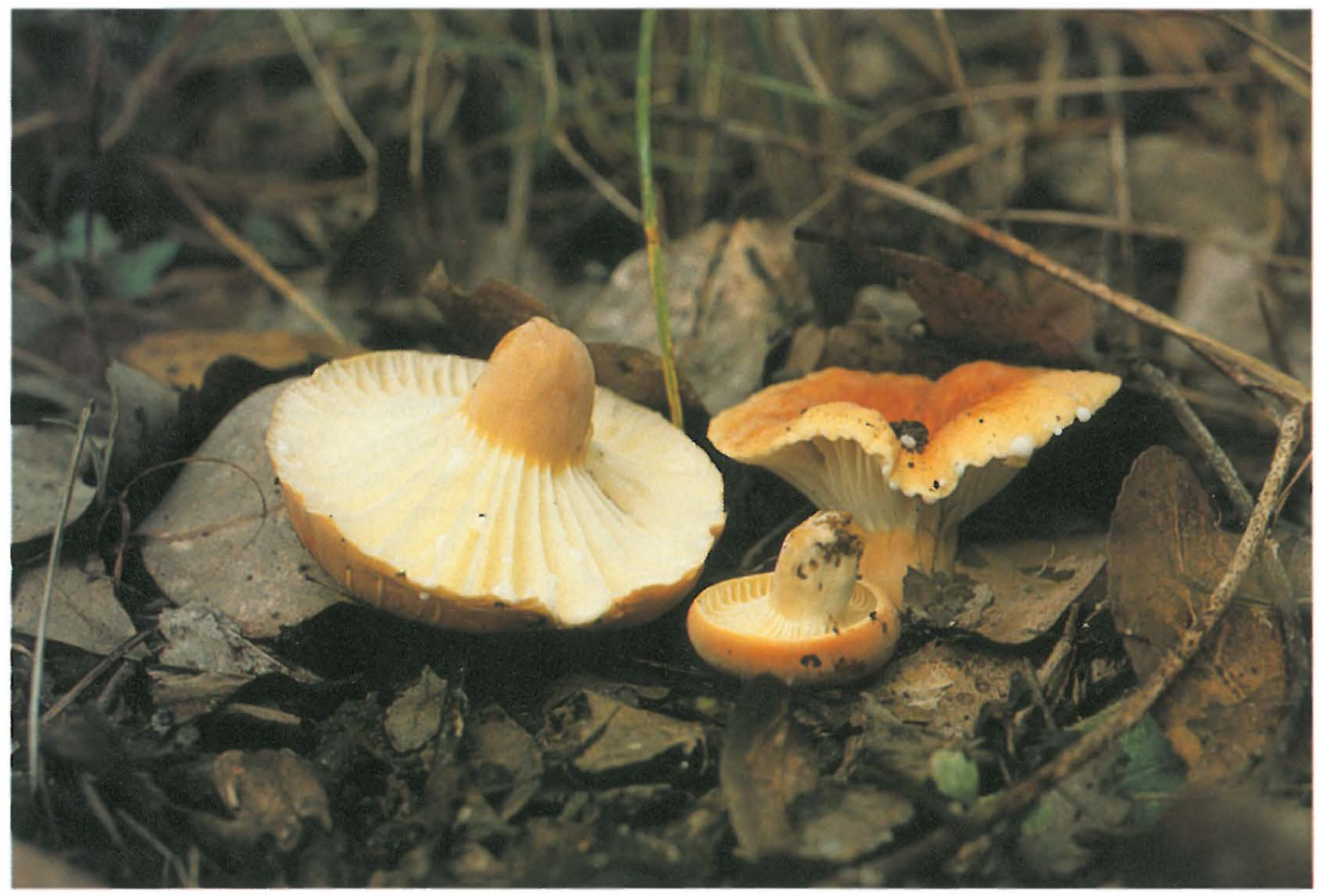

Fig. 6. Fruit bodies of Lactarius volemoides (holotype). L. volemoides resembles L. pseudovolemus and L. volemus. 
Fig. 7. Lactarius volemoides. a) spores, b) basidia, c) marginal cells of pileipellis (holo-
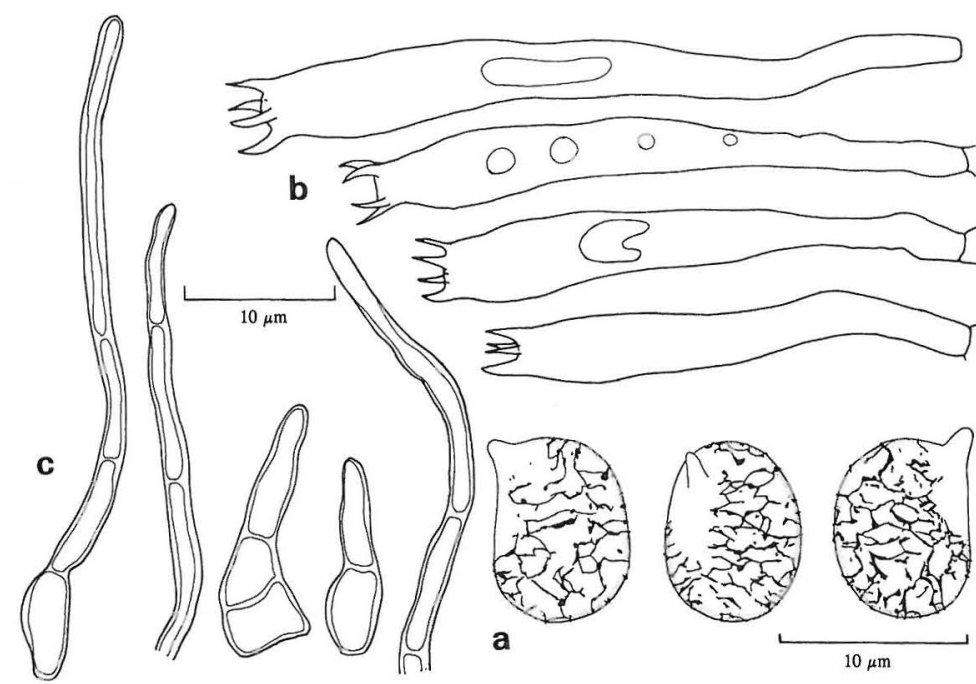
type).

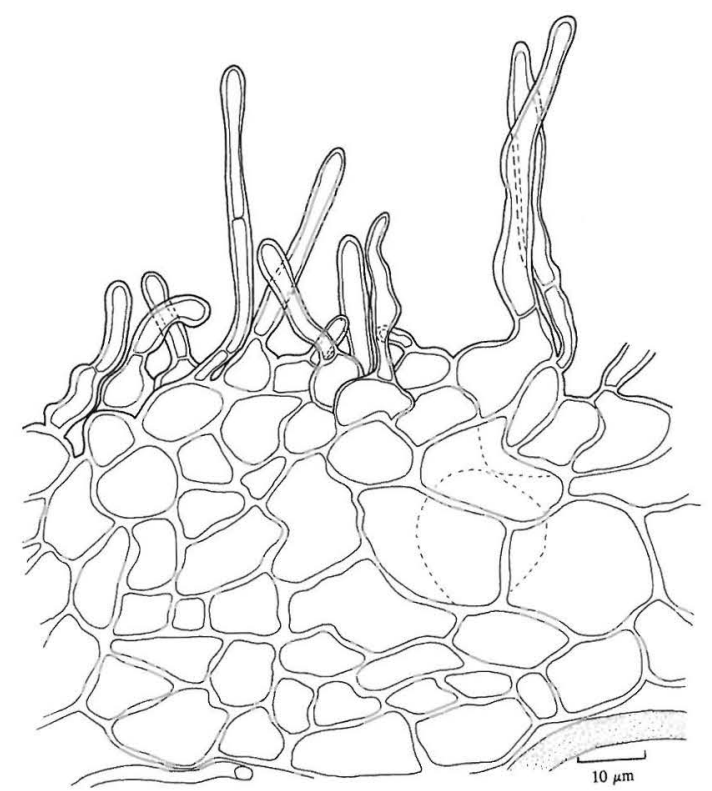

Fig. 8. The structure of pileipellis of Lactarius volemoides (holotype).

Additional specimens examined: Tanzania. Southern Highlands Prov., Mbeya Distr., a few km E of Mbeya, Ipembe Hill (08 33 CD), 1600 m, 28.III.1991 Saarimäki et al. 749. L. pseudovolemus. Madagascar. Betsimarka Prov., S of Maningory, Malagasy lowland rainforest, 12-1934, Heim G61 (holotype, PC).
Observations: In the book 'Edible mushrooms of Tanzania' (Härkönen et al. 1995) this species is illustrated and described as Lactarius sp. aff. pseudovolemus. The type locality of L. pseudovolemus is Malagasy lowland rainforest. $L$. volemoides differs from $L$. pseudovolemus in having paler, white to cream lamellae, by its smell which is similar to that of L. volemus, by its larger spores with lower ornamentation, by its longer basidia and longer elements of the suprapellis and by its habitat being miombo woodland.

Lactarius volemoides belongs in the subgenus Lactifluus (Burl.) Hesler \& A.H. Sm. because of the structure of pileipellis and spore ornamentation. It fits well in subsect. Rugati Pacioni \& Lalli, by the long and slender basidia and the absence of true pleurocystidia.

This mushroom is said to be common at the end of rainy seasons.

Lactarius pumilus Verbeken, Bull. Jard. Bot. Nat. Belg. 65:205. 1996. -Fig. 9

Vernacular names: Wikese, (Nyamwezi); Unyakuvemba (Hehe).

Edibility: Tasty edible mushroom, has to be dried before cooking (Nyamwezi); edible (Hehe).

Ecology: Degraded woodland with Agave sisalana, Brachystegia, Julbernardia, Terminalia, Parinari and Albizia. 
Specimens examined: Tanzania. Western Prov., Tabora Distr., ca. $20 \mathrm{~km} \mathrm{~W}$ of Tabora, Lulanguru village (05 32 BA), 1100 m, 14.XII.1991 1109. Southern Highlands Prov., Iringa Dist., $40 \mathrm{~km} \mathrm{NE}$ of Iringa, Itagutwa village (07 35 DA), 1300 m, 08.II.1993 1603. Burundi. Bururi Prov., Nkayamba, just N of Rumonge, 850 950 m, III.1993 Buyck 5000 (Priv. herb. Buyck).

Observations: L. pumilus is described by Verbeken (1996b). L. pumilus is very small: diameter of pileus is only $1-3.5 \mathrm{~cm}$ and the length of its stipe $1-2.5 \mathrm{~cm}$. This is the only Lactarius species studied from Tanzania where no sphaerocytes were observed in the trama. The microscopical details are illustrated in Verbeken (1996c).

Lactarius medusae Verbeken, Mycotaxon 55:532. 1995. - Fig. 10

Vernacular names: Widziva (Bena), Unyakuvemba (Hehe).

Edibility: Eaten after parboiling and cooking (Hehe).

Ecology: Miombo woodland with Uapaca, few Brachystegia, Garcinia, Eriosema, Ochna, Faurea, Bridelia and Protea.

Specimens examined: Tanzania. Southern Highlands Prov., Iringa Dist., Sao Hill Sawmills (08 35 AC), 1900 m, 29.III.1991 763; Njombe Distr., 11 km S of Kidugala, Mbalali village (09 34 BA), 1650 m, 01.II.1993 1502; Iringa Distr., Mafinga, Sao Hill Misitu (08 35 AD), purchased from a woman who had collected the specimen from nearby miombo woodland, $1800 \mathrm{~m}$, 06.II.1993 1589.

Observations: The microscopical details are illustrated by Verbeken (1995b) based on the material collected by Buyck from Burundi. Verbeken's description agrees with that of our Tanzanian specimens. Before Verbeken published the description of L. medusae, our specimens were misidentified as L. rubroviolascens (Härkönen et al. 1994a). L. medusae differs from L. rubroviolascens in having stronger ornamentation on its spores and much longer elements of suprapellis. Context of $L$. medusae becomes violet and context of $L$. rubroviolascens becomes first blackish then reddish (Verbeken 1996c).

Lactarius denigricans Verbeken \& Karhula, Persoonia 16:219. 1996. - Fig. 11

Vernacular names: Unknown.

Edibility: Local people ignore this peculiar species with rapid colour changes.
Ecology: Degraded miombo woodland growing mainly Uapaca with some Brachystegia.

Specimens examined: Tanzania. Southern Prov., Songea distr., Lirondo village, $120 \mathrm{~km} \mathrm{~N}$ of Songea, $1250 \mathrm{~m}$, 30.I.1993 1467 (holotype, H).

Observations: The microscopical details are illustrated by Verbeken (1996a). The name of this Lactarius species refers to its milk latex which is first white, watery, then bright red and finally turns black. $L$. denigricans resembles $L$. medusae and $L$. rubroviolascens in the colour changes of its milk latex and context and the very emergent and abundant true pleurocystidia but $L$. denigricans differs from these species in its spore ornamentation and pileipellis structure. All the colour changes can be seen in Fig. 11.

Lactarius annulatoangustifolius Verbeken, Edinb. J. Bot. 53:72. 1996. - Fig. 12

Vernacular names and edibility: Not known.

Ecology: Lower montane forest with Dracaena afromontana, Craibia brevecaudata, Isoberlinia and Syzygium.

Specimens examined: Tanzania. Tanga Prov., Lushoto Distr., West Usambara Mts., Mazumbai, Forest Reserve, near the Tanner's house, (04 38 DC), on ground, 1700 m, 17.XII.1995 1700, 1720.

Observations: All other macroscopical and microscopical characters of our specimens are in good agreement with the type specimen of $L$. annulatoangustifolius, but the spores of our specimens are not quite as high-ornamentated as the spores of the type specimen of $L$. annulatoangustifolius. According to Verbeken's drawings (1996d) there is, however, some variation in the ornamentation of the spores of $L$. annulatoangustifolius.

The three species, L. annulatoangustifolius, $L$. heimii and $L$. velutissimus have an annulus around the stipe. L. annulatoangustifolius is easy to recognize by the up to $1 \mu \mathrm{m}$ high warts on the spores. The other two species have very low ornamentation on the spores.

Lactarius heimii Verbeken, Bull. Jard. Bot. Belg. 65:201. 1996. - Fig. 13

Vernacular names: Kansalaghe (common name for inedible mushrooms) (Sukuma); Wikese, (Nyamwezi); Unyakuvemba (Hehe). 


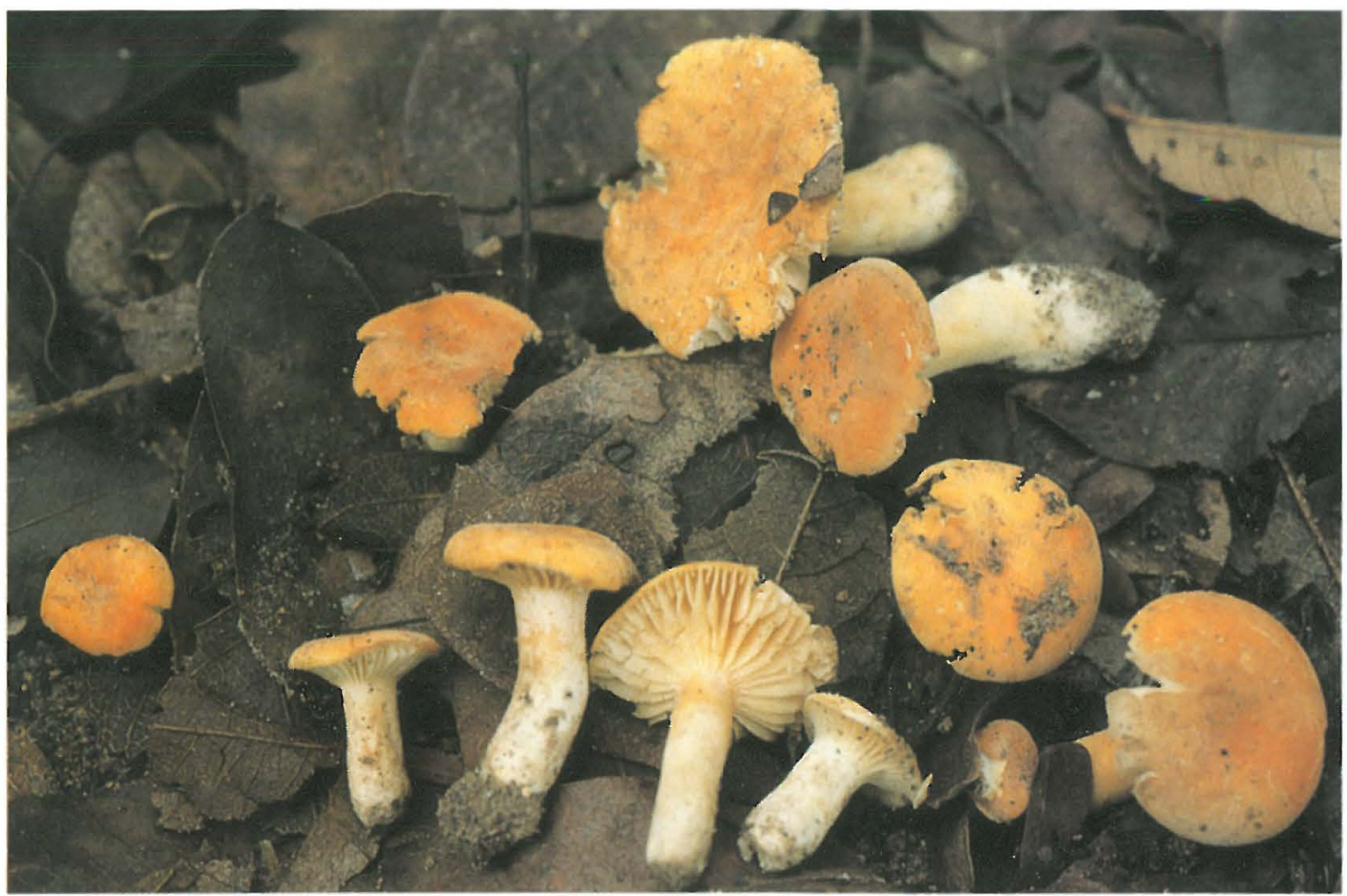

Fig. 9. Fruit bodies of Lactarius pumilus (1109).

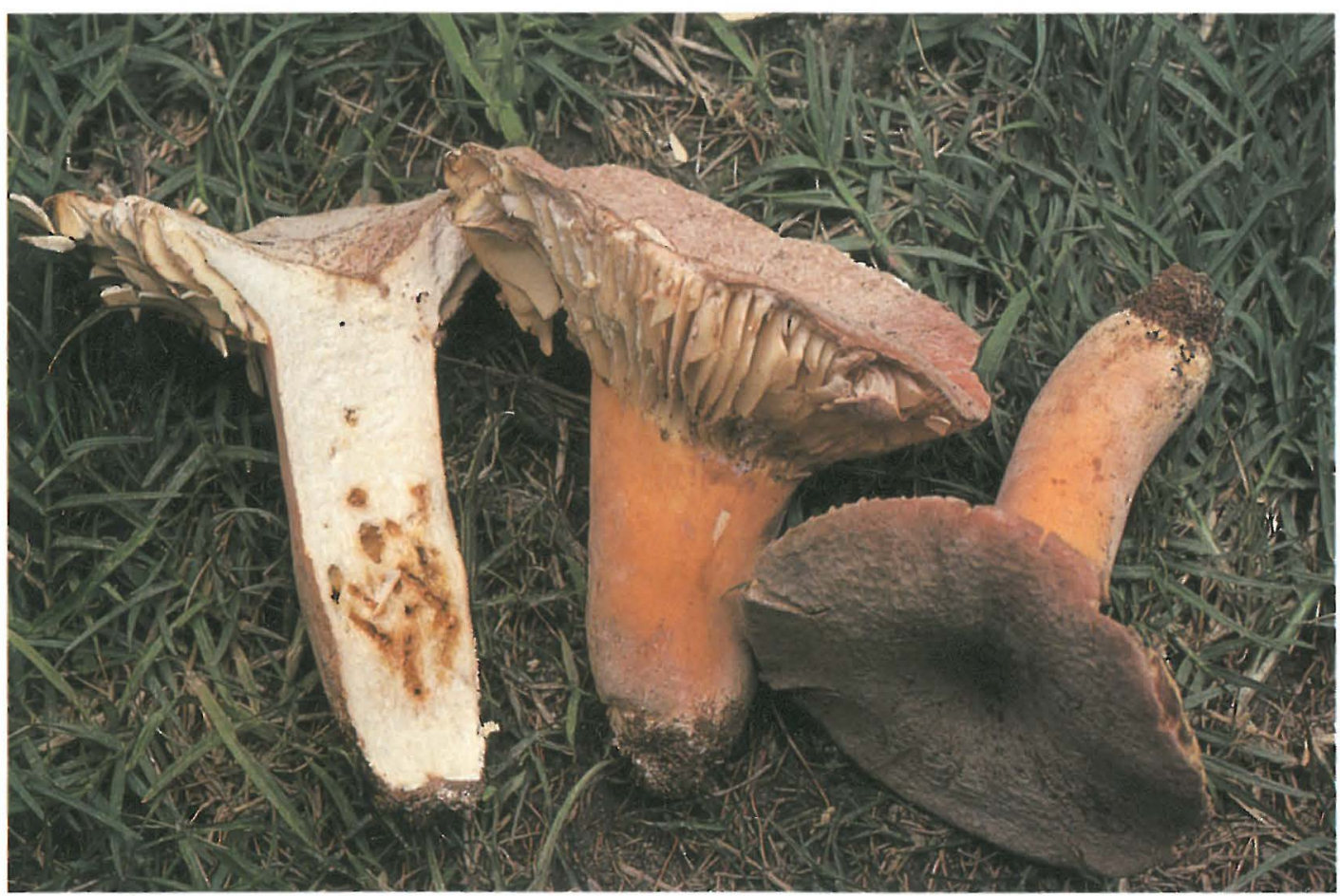

Fig. 10. Fruit bodies of Lactarius medusae (1589). 


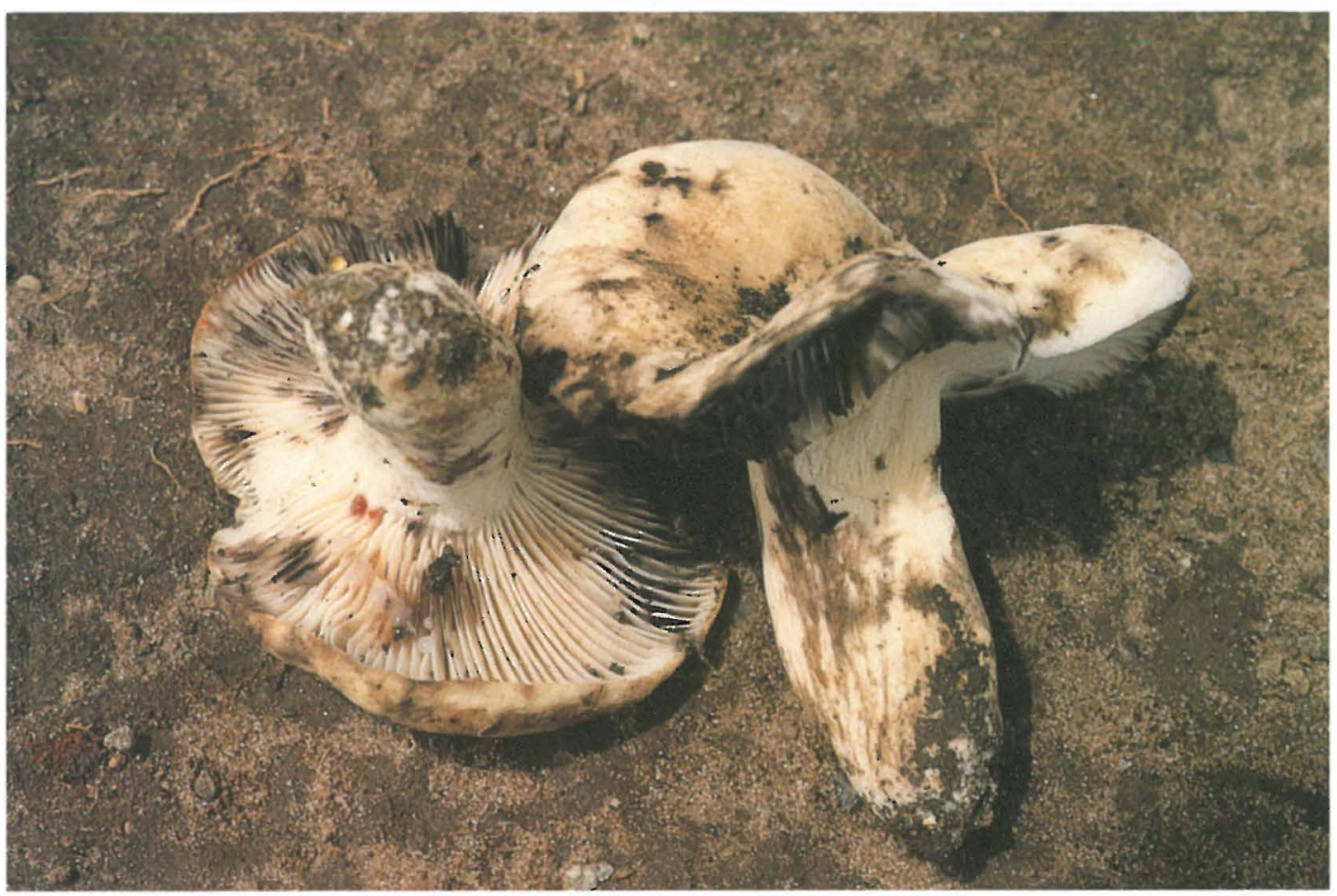

Fig. 11. Fruit bodies of Lactarius denigricans (1467).

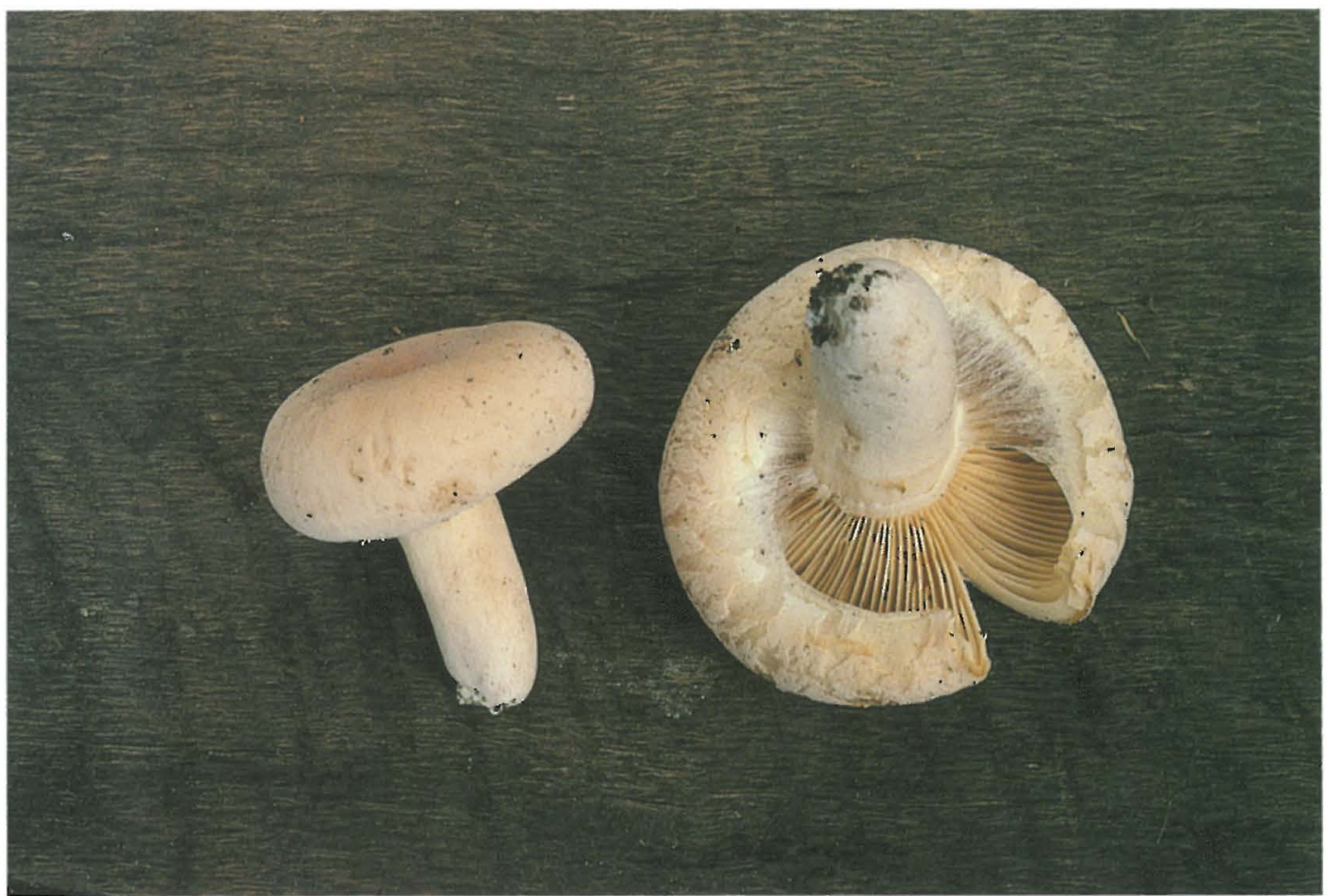

Fig. 12. Fruit bodies of L. annulatoangustifolius (1700). Photo T. Niemelä. 
Edibility: Opinions about its edibility varies a lot. Some Hehe consider it edible, the Nyamwezi think it is edible after drying and boiling, whereas the Sukuma find it inedible.

Ecology: Woodland with Brachystegia, Terminalia, Combretum, Rothmannia, Catunaregam, Psoropteryx, Hyphaene, Agave sisalana, Parinari, Albizia, Euphorbia spinosa and Julbernardia.

Specimens examined: Tanzania. Western Prov., Kahama Distr., ca. $40 \mathrm{~km} \mathrm{SW}$ of Kahama, Mpunze, Forest Reserve (03 32 CD), 1150 m, 10.XII.1991 1034; ca. 45 $\mathrm{km}$ SW of Kahama, Mpunze, Forest Reserve (03 32 CD), 1150 m, 10.XII.1991 1042; Tabora Distr., ca. 20 $\mathrm{km} \mathrm{W}$ of Tabora, Lulanguru village (05 32 BA), , 1100 m, 14.XII.1991 1111. Southern Highlands Prov., Iringa Distr., $40 \mathrm{~km} \mathrm{NE}$ of Iringa, Itagutwa village (07 $35 \mathrm{DA})$, 1300 m, 08.II.1993 1600, 1607.

Observations: Lactarius heimii macroscopically resembles $L$. neotropicus described from the Lesser Antilles (Pegler \& Fiard 1979). L. heimii, however, has larger, more elongate $(\mathrm{Q}=1.29$ for $L$. heimii vs. $\mathrm{Q}=1.12$ for $L$. neotropicus) and lower ornamentated spores.

Misappl.: L. pelliculatus (Beeli) Buyck in Härkönen et al. $(1994 a)=L$. heimii .

Lactarius velutissimus Verbeken, Bull. Jard. Bot. Belg. 65:212. 1996. - Fig. 14

\section{Vernacular names: Unknown.}

Edibility: Inedible (Bena); edible (Ngoni).

Ecology: Degraded miombo woodland with Brachystegia, Julbernardia, Uapaca, Syzygium, Combretum, Uapaca, Garcinia, Eriosema, Ochna, Faurea, Bridelia and Protea.

Specimens examined: Tanzania. Southern Prov., Songea Distr., $29 \mathrm{~km}$ from Songea towards Mbinga, Matomondo (10 35 CB), 800 m, 29.I.1993 1454. Southern Highlands Prov., Njombe Distr., Mbalali village $11 \mathrm{~km}$ south of Kidugala (09 $34 \mathrm{BA}$ ) red soil, $1650 \mathrm{~m}$, 01.II.1993 1515 .

Observations: The pileipellis of $L$. velutissimus is thicker, paler coloured and clearly stellately rupturing while in $L$. heimii the pileipellis is darker, more cracked and irregularly rupturing towards the margin. Microscopically L. heimii is easily recognized by its longer spores (Verbeken 1996c).
Lactarius xerampelinus Karhula \& Verbeken sp. nov. -Figs. 15-18

Pileus 5-12 cm diam., primo convexus et in centro leviter depressus, deinde infundibuliformis, pileipellis xerampelina, impolita, marginem versus pruinosa. Lamellae subdecurrentes, subdistantes, pallide cremeae. Stipes $2-6 \mathrm{~cm}$ longus, $1-$ $3 \mathrm{~cm}$ crassus, pallide ochraceus, subtiliter scrobiculatus. Contextus albidus, ochracescens, gustu mitis. Latex abundans, albidus. Sporae ellipsoidae, 7.5-8.7-10 × 5-5.9-7 $\mu \mathrm{m}$, verrucis saepe isolatis interdum connectis ornatae, macula suprahilaris in parte amyloidea. Basidia 60-70 $\times \quad 7-9 \mu \mathrm{m}$. Pleurocystidia vera absentia. Pileipellis ex catenis elementorum elongatorum, elementa terminalis $20-35 \times 6-10 \mu \mathrm{m}$, clavata vel cylindrata.

Holotype: Tanzania. Western Prov., Tabora distr., ca. $20 \mathrm{~km}$ w of Tabora, Lulanguru village (05 32 BA), 1100 m, 14.XII. 1991 Saarimäki et al. $1116(\mathrm{H}$, isotype GENT and DSM).

Pileus $5-12 \mathrm{~cm}$ in diameter, at first convex with central depression, then depressed to funnelshaped, margin in old specimens irregular, wavy. Surface dark red-brown, matted, at margin pruinose, in old specimens finely areolate. Gills shortly decurrent, sub-distant with several lamellulae, fairly thick, up to $5 \mathrm{~mm}$ broad, pale cream, margin entire. Stipe 2-6 × 1-3 cm, variable in shape, cylindric to tapering, pale ochraceous, matted, weakly scrobiculate. Context in cap up to $13 \mathrm{~mm}$ thick, white, turning ochraceous on bruising; in stipe similar to cap, solid, milk latex white, abundant. Smell fresh, fruity. Taste mild, pleasant. Spore print pale cream.

Spores 7.5-8.7-10 × 5-5.9-7 $\mu \mathrm{m},(\mathrm{Q}=1.29$ 1.48-1.67; $\mathrm{n}=152$ ), ellipsoid, ornamentation amyloid, punctate with few very fine connective lines, plage partly amyloid. Basidia 4-spored, 60-70 × 7-9 $\mu \mathrm{m}$. True pleurocystidia absent. Pseudopleurocystidia abundant, 3-5 $\mu \mathrm{m}$ in diameter. Lamella-edge sterile, marginal cells thinwalled, cylindrical, tapering upwards, 70-80 $\times 10$ $\mu \mathrm{m}$. Hymenophoral trama composed of sphaerocytes, lactifers $4 \mu \mathrm{m}$ in diameter. Pileipellis trichopalisade, composed of elongate, thin-walled cells forming chains, terminal cells $20-35 \times 6-10$ $\mu \mathrm{m}$, clavate or cylindrical. Stipitipellis trichodermlike composed of repent, thin-walled hyphae, the hyphal tips projecting outwards. Clamp connections absent. 


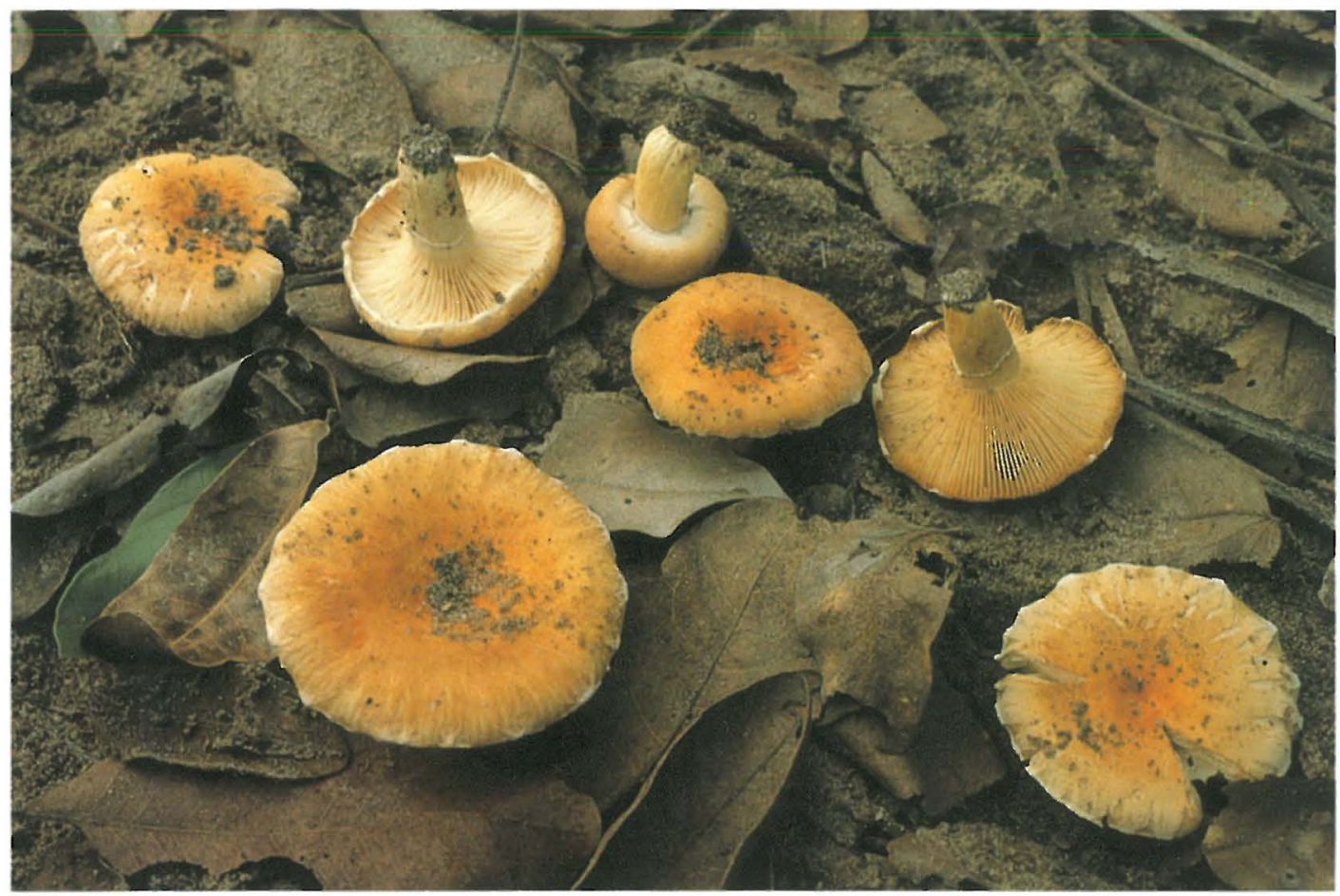

Fig. 13. Fruit bodies of Lactarius heimii (1034).

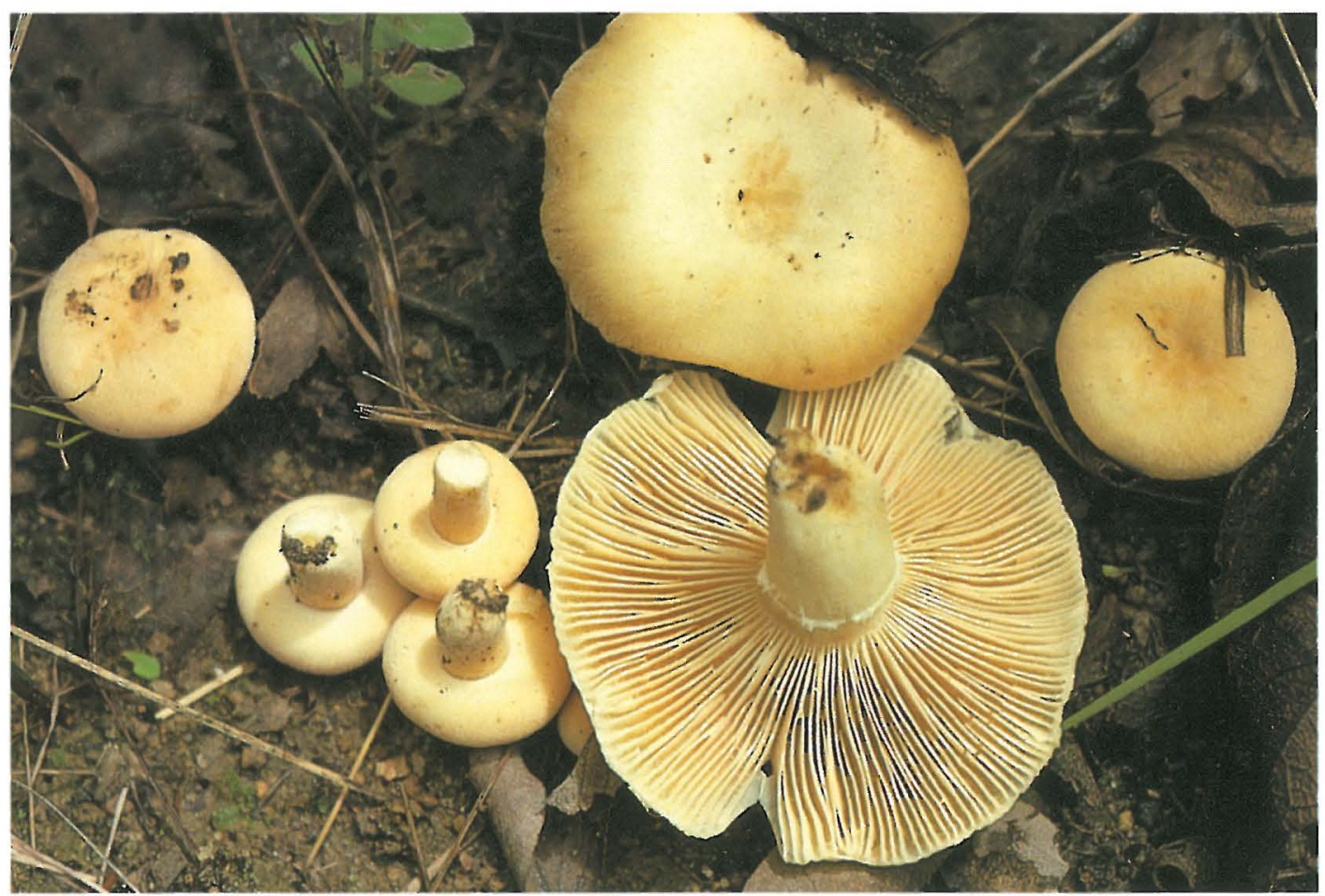

Fig. 14. Fruit bodies of Lactarius velutissimus (1515) are paler than fruit bodies of $L$. heimii. Photo T. Niemelä. 


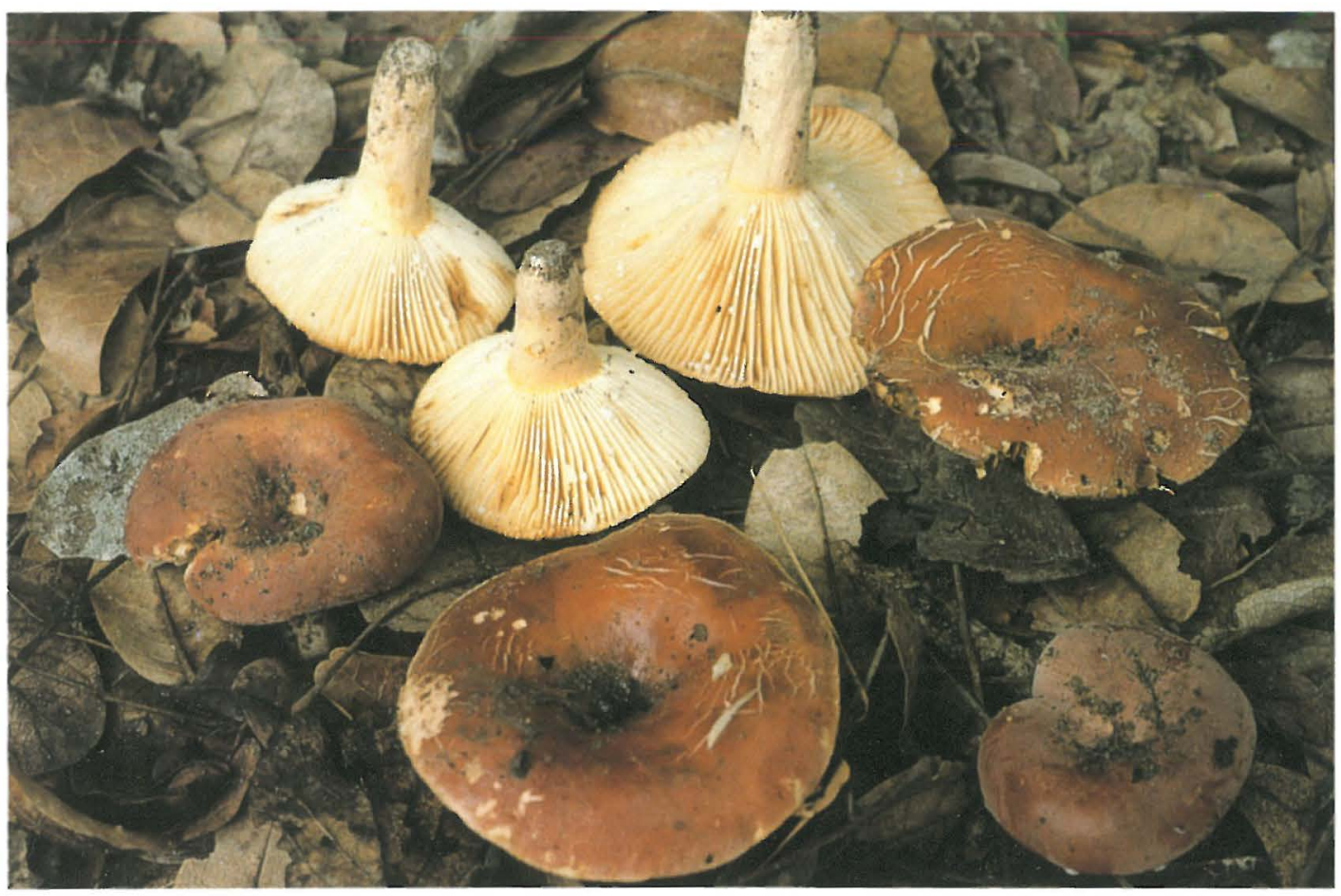

Fig. 15. Fruit bodies of Lactarius xerampelinus (holotype). Xerampelinus means dull red with a strong mixture of brown.

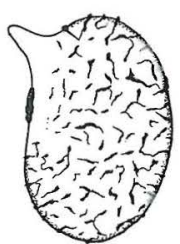

a

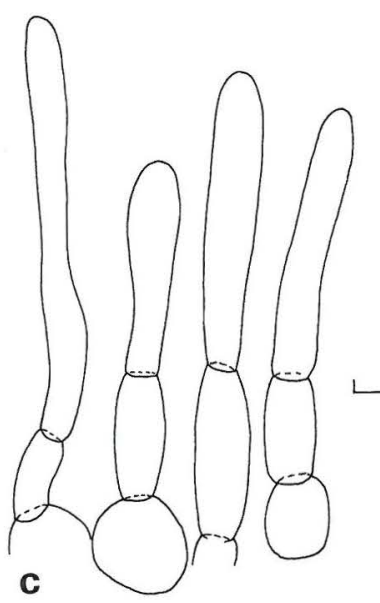

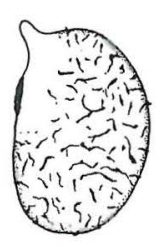

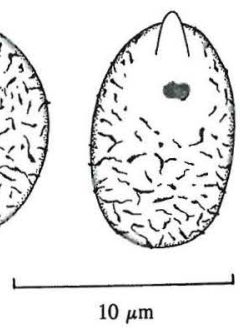

$10 \mu \mathrm{m}$
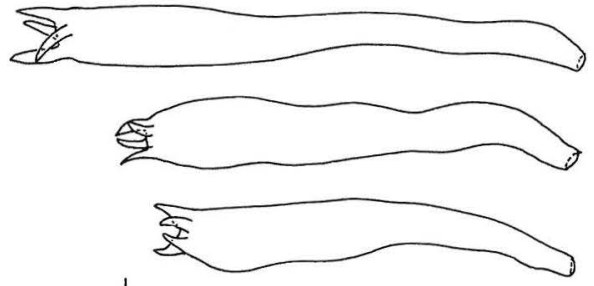

$10 \mu \mathrm{m}$

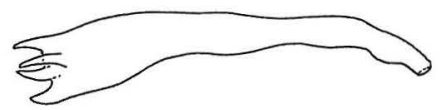

d

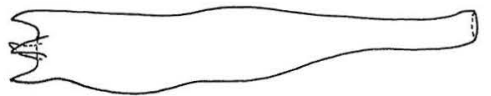

Fig. 16. Lactarius xerampelinus. - a) spores, b) basidia, c) marginal cells, d) marginal cells of pileipellis (holotype). 


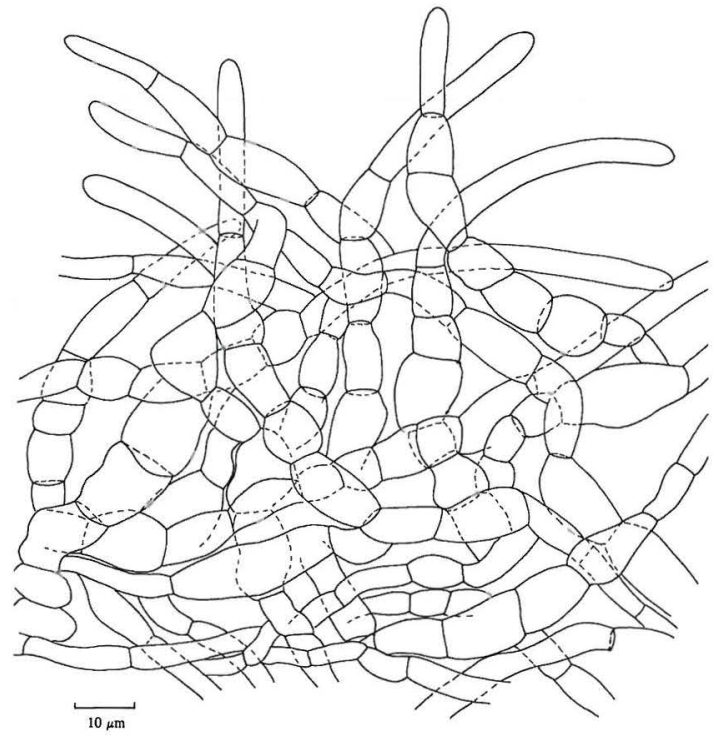

Fig. 17. The structure of pileipellis of Lactarius xerampelinus (1604).

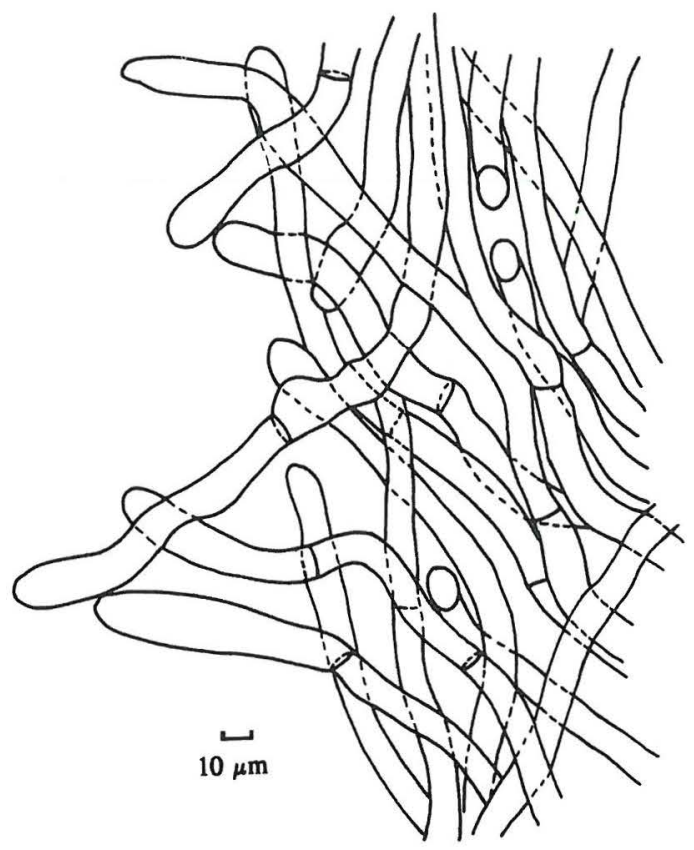

Fig. 18. The structure of stipitipellis of Lactarius xerampelinus (holotype).

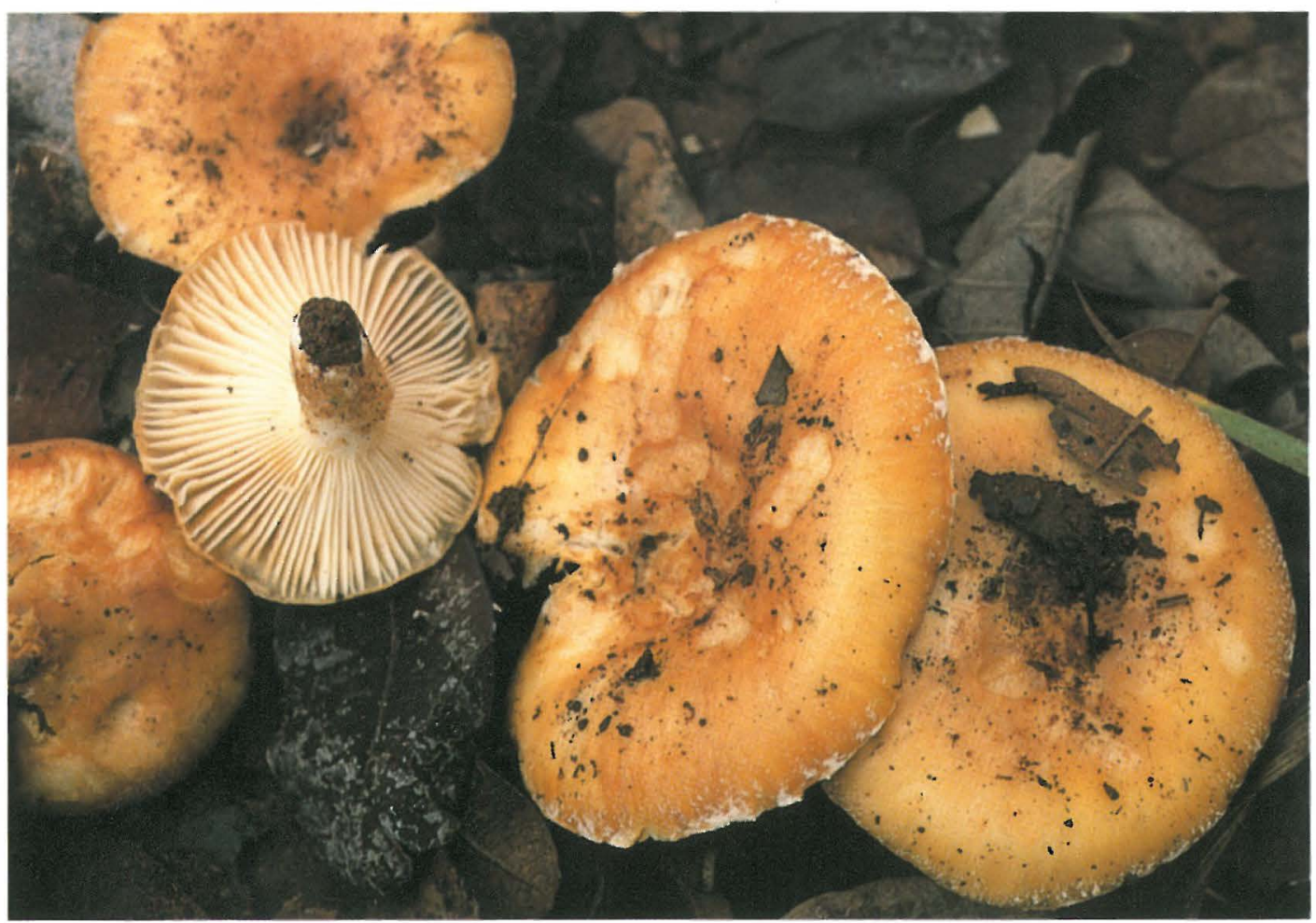

Fig. 19. Fruit bodies of Lactarius laevigatus (1485). 
Vernacular names: Wimenda (Hehe), Kikoba (Nyamwezi), Bushikoba (Sukuma).

Edibility: Edible, can be cooked without parboiling or drying. Often sold at market places.

Ecology: Degraded woodland with Agave sisalana, Brachystegia, Terminalia, Parinari, Albizia and Julbernardia.

Additional specimens examined: Tanzania. Western Prov., Tabora Distr., Urambo, purchased in Urambo market (05 32 AA), ca. 1070 m, 13.XII. 1991 1090; ca. $20 \mathrm{~km} \mathrm{~W}$ of Tabora, Lulanguru village (05 $32 \mathrm{BA}$ ), 1100 m, 14.XII. 1991 1114, 1121. Southern Highlands Prov., Iringa Distr., $40 \mathrm{~km}$ NE of Iringa, Itagutwa village $(07$ 35 DA), 1300 m, 8.II.1993 1604. Lactarius phlebophyllus: Madagascar. Betsimisaraka Prov., Anosibé, S of Soanierana, Malagasy lowland rainforest, XII-1934, Heim G87 (holotype, PC).

Observations: This species microscopically resembles Lactarius phlebophyllus R. Heim, having similar type of pileipellis and lacking true pleurocystidia. L. xerampelinus differs from $L$. phlebophyllus having lower spore ornamentation and trichoderm-like stipitipellis whereas $L$. phlebophyllus has trichopalisade-like stipitipellis. According to Verbeken (1996c) the microscopic characters of L. phlebophyllus are very similar to those of L. latifolius Verbeken. L. xerampelinus differs from $L$. latifolius having clearly ellipsoid spores whereas L. latifolius has almost globose spores. The three species have a somewhat reddish brown pileus. The habitat of L. latifolius and L. gymnocarpus is rainforest whereas L. xerampelinus grows on miombo woodland.

Xerampelinus means dull red with a strong mixture of brown. L. xerampelinus is related to $L$. edulis Verbeken and L. densifolius Verbeken \& Karhula because of the dry, slightly tomentose pileipellis, trichopalisade-type structure of pileipellis and very low spore ornamentation (Verbeken 1996c).

Lactarius xerampelinus is included in the book on Tanzanian mushrooms (Härkönen et al. 1995) as L. sp. aff. phlebophyllus. Härkönen et al. (1994a) mention L. xerampelinus as L. cf. phlebophyllus.

Lactarius laevigatus Verbeken, Bull. Jard. Bot. Belg. 65: 203. 1996. - Fig. 19

Vernacular names: Wunyamalagata (Bena); Ungujuu (Ndendeuli).
Edibility: Has to be boiled first then dried (Bena); edible (Ndendeuli).

Ecology: Miombo woodland with Brachystegia, Julbernardia, Combretum, Albizia, Pterocarpus, Protea, Faurea, Parinari, Uapaca, Rothmannia, Combretum molle, Garcinia and Gardenia.

Specimens examined: Tanzania. Lake Prov., Mwanza Distr. Geita, a few km W of Geita (02 $32 \mathrm{CD})$, ca. 1250 m, 5.XII.1991 1006a. Southern Prov., Masasi Distr., Rukohe village (10 39 AC), 550 m, 22.I.1993 1326; Songea Distr., about $40 \mathrm{~km} \mathrm{~N}$ of Songea, Hanga, Nyamagoma village (10 $35 \mathrm{BC}$ ), $990 \mathrm{~m}, 27 . \mathrm{I} .19931428$. Southern Highlands Prov., Njombe Distr., Ngaramiro, 2 $\mathrm{km} \mathrm{N}$ of Kidugala (09 $34 \mathrm{BA}$ ), on hill slope, red soil, 1550 m, 31.I.1993 1485. Zambia. Copperbelt Prov., Chati-forest, near Kitwe, degraded miombo woodland, under Albizia adantifolia, 1274 m, 12-1990 Buyck 3211 (Priv. herb. Buyck).

Observations: We compared the Tanzanian specimens to the specimen Buyck 3211 collected from Zambia. The structure of pileipellis, marginal cells, basidia, pseudopleurocystidia, and structure of hymenophoral trama are similar in all of the five specimens. We could not find any difference in spore ornamentation either, but specimen 3211 has spores which are a bit more rounded than those of our specimens (3211: $\mathrm{Q}=1.29, \mathrm{n}$ $=20$; specimens $1006 a, 1326,1428$ and $1485: \mathrm{Q}$ $=1.39, \mathrm{n}=80$ ). Because the shape of the spores is the only difference we concluded, these specimens are conspecific. L. laevigatus has strongly striate, smooth, light orange to greyish orange pileus and an ixocutis-like to trichoderm-like pileipellis (Verbeken 1996c).

Lactarius edulis Verbeken \& Buyck, Publications Agricoles 34: 103. 1994. - Fig. 20

\section{Vernacular name: Wisimba (Hehe) \\ Ecology: Miombo woodland.}

Specimens examined: Tanzania. Western Prov., Tabora Distr., Tabora, purchased in the dried form at Tabora market (05 32 BB), 12.XII.1991 1057a. Southern Highlands Prov., Iringa Distr., Mafinga, Sao Hill Misitu (08 $35 \mathrm{AD}$ ), purchased from a woman who had collected specimen from nearby miombo woodland, 6.II.1993 1588.

Observations: L. edulis has fleshy and firm context and trichopalisade-like pileipellis. The microscopical details were illustrated by Verbeken (1995a). Härkönen et al. (1995) have published the first record of L. edulis for Tanzania. 


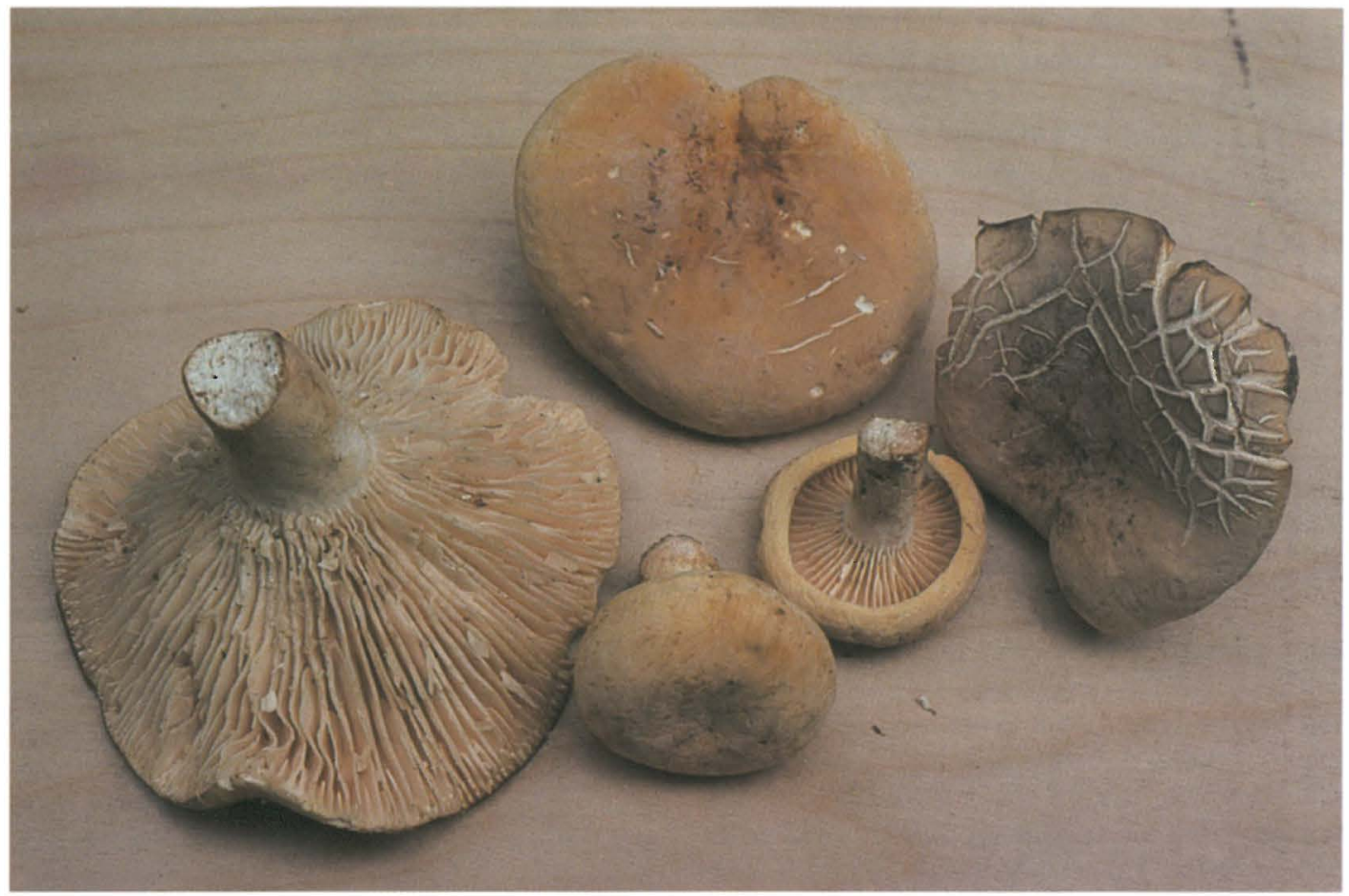

Fig. 20. Lactarius edulis (1588).

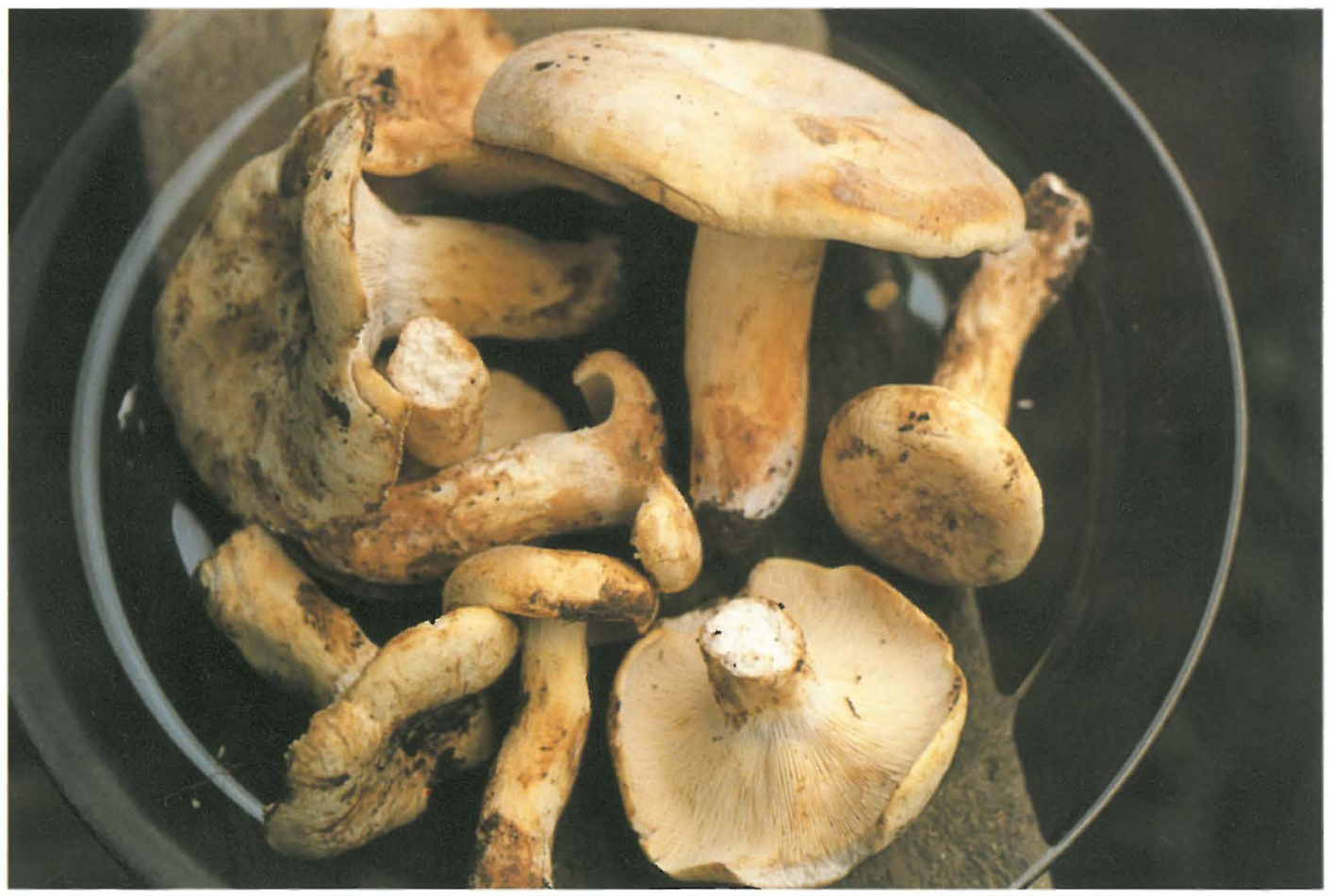

Fig. 21. Fruit bodies Lactarius densifolius (1479). Lactarius densifolius resembles L. inversus but has much denser lamellae. 


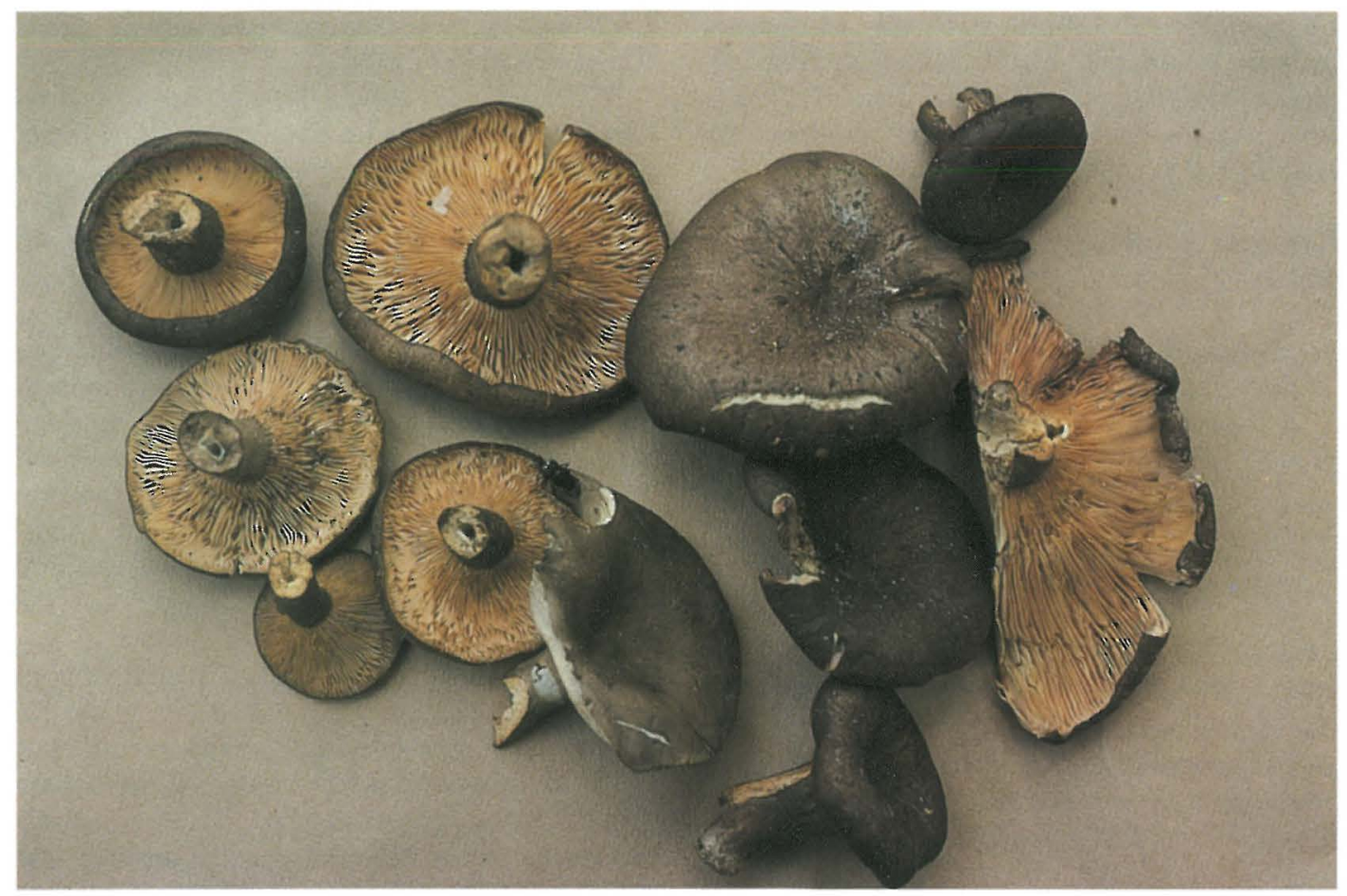

Fig. 22. Fruit bodies of Lactarius kabansus (1089).

Lactarius densifolius Verbeken \& Karhula Bull. Jard. Bot. Nat. Belg. 65: 200. 1996. - Fig. 21

Vernacular names: Wifwimi = 'eagerly hunted', Ulyafwimi, Wifimi, Vulwafwimi, Widziwa (Bena).

Edibility: can be eaten without parboiling, some interviewees consider this as the best of all mushrooms (Bena).

Ecology: Degraded miombo woodland with Brachystegia, Julbernardia, Uapaca, Syzygium, Ochna, Parinari, Rothmannia, Combretum molle, Garcinia and Gardenia.

Specimens examined: Tanzania. Southern Prov., Songea Distr., $29 \mathrm{~km}$ from Songea towards Mbinga, Matomondo (10 35 CB), 800 m, 29.I.1993 1449; Lirondo village, $120 \mathrm{~km} \mathrm{~N}$ of Songea (09 $35 \mathrm{CD}), 1250 \mathrm{~m}$, 30.I.1993 1468. Southern Highlands Prov., Njombe Distr., Kidugala (09 34 BA), specimens were brought to us by some small children, 1550 m, 30.I.1993 1474; Ngaramiro, $2 \mathrm{~km} \mathrm{~N}$ of Kidugala (09 $34 \mathrm{BA}$ ), on hill slope, red soil, 1550 m, 31.I.1993 1479, 1489; N of Kidugala, between the villages of Sengele and Masaulwa, (0934 BA), 1500 m, 2.II.1993 1524; N of Kidugala, Masaulwa village, (09 $34 \mathrm{BA})$, purchased from a woman who was preparing mushrooms for drying, $1500 \mathrm{~m}$, 2.II.1993 1543.
Observations: Lactarius densifolius resembles L. inversus Gooss.-Font. \& R. Heim.

L. densifolius has, however, clearly denser lamellae and lower spore ornamentation than $L$. inversus. According to Verbeken (1996c) the pileipellis is trichopalisade in L. inversus and trichoderm in $L$. densifolius. A colour picture has also been published by Buyck (1994) under the name 'L. inversus'.

Lactarius kabansus Pegler \& Piearce, Kew Bull. 35: 487. 1980.-Fig. 22

Vernacular names: Wisigisa (Hehe), Umpalala (Nyamwezi)

Edibility: Edible and popular, does not need to be parboiled. Sold in market places.

Ecology: Miombo woodland.

Specimens examined: Tanzania. Western Prov., Tabora Distr., Urambo, purchased from Urambo market (05 32 AA), 13.XII.1991 1089. Southern Highlands Prov., Iringa Distr., Mafinga, Sao Hill Misitu, purchased from a woman who had collected the specimen from nearby miombo woodland (08 35 AD), 6.II.1993 1590. 
Observations: L. kabansus is easily recognized by its dark coloured, small fruit bodies and hymeniderm-like pileipellis. The first record of Lactarius kabansus from Tanzania was published by Härkönen et al. (1995).

Lactarius chromospermus Pegler, Kew Bull. 37: 269. 1982.

Vernacular names: no given names.

Edibility: inedible (Bena).

Ecology: Miombo woodland with Brachystegia and Uapaca.

Specimens examined: Tanzania. Southern Highlands Prov., Njombe Distr., between the villages of Sengele and Masaulwa, (09 34 BA), 1500 m, 2.II.1993 1539.

Observations: The name refers to its dark brown spores. Buyck and Verbeken (1995) discussed the microscopical features and the ecology of $L$. chromospermus in detail. We found similar differences between our measurements and Pegler's description as did Buyck and Verbeken.

Lactarius cyanovirescens Verbeken, Bull. Jard. Bot. Belg. 65:199. 1996.

Vernacular names: Unknown.

Edibility: Woman, who had been hospitalized because of mushroom poisoning, said that this fungus is inedible (Hehe).

Ecology: Degraded miombo woodland dominated by Uapaca.

Specimens examined: Tanzania. Southern Highlands Prov., Iringa Distr., Mafinga, Changarawe village (08 35 AD), 1750 m, 5.II.1993 1578. Burundi. Bururi Prov., Rumonge Forest Reserve, Nyamirambo, dominated by Brachystegia utilis, 850-950 m, III-1994 Verbeken 94.156 (BR).

Observations: L. cyanovirens has smooth, dry, brownish orange to light brown, or greyish red pileus and cutis-like pileipellis.

\section{Edibility of Lactarius in Tanzania}

Tanzanians have hundreds of vernacular names for mushrooms and it seems to us they have no logical system for classifying them. During the interviews it was noteworthy that the genus Lactarius, however, is recognized by many people. At least the Bena even have a collective name for
Lactarius species, Unyamaziwa, which means 'fungi which exude milk'.

When people collect mushrooms for food they identify them with the same method many researchers use. After picking a mushroom, they break a bit of it to see if it is brittle or tough. Then they smell it and taste it. Some people reject all bitter or acrid species but others have made the same discovery used by people as far north as Finland. Before cooking the bitter Lactarius species for food they boil them for a short time and then throw the water away. We ourselves tasted all the specimens in the fresh form and found out that among the Tanzanian Lactarius there are many more mild species than among the Lactarius of the boreal zone. Some, for instance, $L$. kabansus and $L$. volemoides are eaten raw in the field.

Only four tribes, the Arusha, Chagga, Maasai and Meru, of the interviewed 35 tribes do not use mushrooms for food. At least among members of the Bena, Mwera and Ndendeuli tribes there are contradictory opinions about Lactarius, some eat them, others ignore them and assume that they are inedible or even poisonous. The same member of the Bena tribe claimed that mushrooms that exude milk latex were poisonous, but considered Lactarius volemoides to be the best edible fungus. The Lactarius species which have a veil around the stipe, L. heimii and $L$. velutissimus, are unpopular. These fungi are considered inedible or edible but never delicious. In miombo woodland Lactarius is considered the fourth best fungus group after Termitomyces, Amanita and Cantharellus. Tribes that at least once mentioned some Lactarius to be the best edible fungi are the Bena, Hehe, Makonde and Nyamwezi. In mountain areas people consider Lactarius to be inedible, even if some species are found also in mountain forests. Wood-rotting fungi are preferred there.

Tanzanians dry the fruit bodies of Lactarius for storage. The mushrooms are cut into pieces and spread on a mat or an iron sheet in the sunshine. Some, at least the acrid species, are parboiled before drying. In that case the dried mushrooms become very hard and need a long soaking or even grinding before use. Dried mushrooms are also offered for sale in the market places. Dried Lactarius are often sold mixed with dried Cantharellus. 


\section{Comparison of Lactarius and Russula}

According to the classic division the fruit bodies of the genus Russula contain sphaerocytes in the hymenophoral trama whereas they are lacking in the hymenophoral trama of the genus Lactarius (Pegler 1977, Ryvarden et al.1994). However, Singer (1986) found sphaerocytes in the hymenophoral trama of some tropical Lactarius species. We noticed that all the Tanzanian Lactarius specimens which Härkönen and Saarimäki collected, except $L$. pumilus, had sphaerocytes in their hymenophoral trama. According to Verbeken (1996c), in some tropical African Lactarius species, the hymenophoral trama looks exactly like the hymenophoral trama of Russula: completely composed of clusters of sphaerocytes. Lactifers are present between the sphaerocytes, but they may also occur in the hymenophoral trama of Russula. The only true microscopic difference between the genera is the presence (in Lactarius) or absence (in Russula) of pseudocystidia, tips of lactifers without septae, in the hymenium as observed by Buyck $(1989,1995)$.

\section{Lactarius in Tanzania}

Härkönen and Saarimäki collected the biggest amount of Lactarius specimens from Southern Highland Province (39 collections). According to Pegler (1977) and White (1983) the vegetation in southern and western Tanzania is similar to the vegetation in Malawi. Therefore we supposed to find also in Tanzania the five Lactarius species (L. luteopus, L. densifolius, L. kabansus var. pallidus, L. gymnocarpoides and L. medusae) which Morris had collected from Malawi (Morris 1990, Verbeken 1996c). We found all of them, except $L$. kabansus var. pallidus, in our material.

Verbeken (1996c) has described L. urens and L. subamarus from Burundi and L. rubiginosus and L. kabansus var. pallidus from Zambia, which have been found from Tanzania, too. Together with our specimens 20 species and one variety of Lactarius have been reported from Tanzania. Together with the still undescribed species we found 27 species of Lactarius. Because of the big amount of species among only 72 collections we assume that there is a large diversity of Lactarius species in Tanzania. According to Buyck (1995) before the year 2000 at least another 200 new Russulales species will be described from tropical areas only.

\section{Edibility of Lactarius in other African countries}

We found information about the edibility of Lactarius only in Burundi, Malawi, Zambia, Zaire and South Africa (Williamson 1975, Parent \& Thoen 1977, Piearce 1981a-b, Buyck 1994, van der Westhuizen \& Eicker 1994, Verbeken 1996c). L. edulis is eagerly sought after both in Burundi and Tanzania (Buyck 1994, Verbeken 1995a, 1996c). According to Piearce (1981a) there is a wide variety of Russula and Lactarius in Zambia, however, many of them are considered inedible because of a peppery or otherwise unpleasant taste. Most of the edible and commercial species belong to the genus Lactarius. According to Pegler \& Piearce (1980) and Piearce (1981a) L. kabansus is gathered in vast quantities from the woodlands of Zambia and it is one of the first mushrooms to appear at roadside markets in November or December. L. kabansus is commonly eaten raw in Zambia and also in Tanzania. Some of the Lactarius and certain Russula are eaten in Zaire, whilst others, such as L. velutissimus and Russula annulata are rejected. Lactarius are preserved in the same way in Tanzania, Malawi, Zambia and Zaire; they are sun-dried (Williamson 1975, Parent \& Thoen 1977, Piearce 1981a). Some Lactarius are parboiled before drying in Tanzania, Zambia and Zaire (Parent \& Thoen 1977, Piearce 1981b). In some parts of Zambia Russula and Lactarius in particular are smoked before storage (Piearce 1981a).

In the book 'Mushrooms of Southern Africa' (van der Westhuizen \& Eicker 1994) only two Lactarius species, L. deliciosus and L. hepaticus are mentioned. Both the species grow on pine plantations and are of northern temperate origin. The native Lactarius species and their edibility in South Africa have probably not yet been studied.

Acknowledgements. Several persons have encouraged and helped us during the course of the work. Dr. Tuomo Niemelä and Mr. Kalevi Härkönen took part in some of the field trips. During the field work Härkönen and Saarimäki got accomodation and assistance from almost every missionary family of the Finnish Evangelical Lutheran Church in Tanzania. Mr. Modest Mrecha from the Mazumbai Forest Station and several Tanzanians in various villages helped and guided us during the field work. We wish to thank Dr. Ilkka Kytövuori for his useful advice at the beginning of the identification work. The Botanical Museum (Helsinki University) provided rooms and laboratory facilities. Dr. Bart Buyck and Dr. 
Ilkka Kytövuori gave useful and critical comments concerning the manuscript. Donald Smart revised the English of the manuscript. The research was financed by the Finnish International Development Agency of the Ministry for Foreign Affairs (FINNIDA), the Academy of Finland and the University of Helsinki.

\section{References}

Buyck, B. 1989: Revision du genre Russula Persoon en Afrique Centrale. - Ph.D. dissertation, Rijksuniversiteit Gent, Part 1:1-318, part 2:1-519, iconography 444 photograps (mimeo).

Buyck, B. 1991: The study of microscopic features in Russula 2. Sterile cells of the hymenium. - Russulales News 1:62-85.

Buyck, B. 1994: Ubwoba: Les champignons comestibles de l'Ouest du Burundi. - AGCD, Publ. Agricoles 34:1124.

Buyck, B. 1995: Towards a global and integrated approach on the taxonomy of Russulales. - Russulales News 3:3-17.

Buyck, B. \& Verbeken, A. 1995: Studies in tropical African Lactarius species. 2. Lactarius chromospermus Pegler. - Mycotaxon 56:427-442.

Calonge, F.D., Härkönen, M., Saarimäki T. \& Mwasumbi, L. 1997: Tanzanian mushrooms and their uses 5. Some notes on the Gasteromycetes. - Karstenia 37:3-10.

Härkönen, M. 1995: An ethnomycological approach to Tanzanian species of Amanita. - Acta Univ. Ups. Symb. Bot. Ups. 30:145-151.

Härkönen, M., Buyck, B., Saarimäki, T. \& Mwasumbi, L. 1993a: Tanzanian mushrooms and their uses 1 . Russula. - Karstenia 33:11-50.

Härkönen, M., Saarimäki, T. \& Mwasumbi, L. 1993b: Tanzanian mushrooms and their uses 2 . An edible species of Coprinus section Lanatuli. - Karstenia 33:5159.

Härkönen, M., Saarimäki, T. \& Mwasumbi, L. 1994a: Edible and poisonous mushrooms of Tanzania. - African J. Mycol. and Biotechnol. 2:100-123.

Härkönen, M., Saarimäki, T. \& Mwasumbi, L. 1994b: Tanzanian mushrooms and their uses 4 . Some reddish edible and poisonous Amanita species. - Karstenia $34: 47-60$.

Härkönen, M., Saarimäki, T. \& Mwasumbi, L. 1995: Edible mushrooms of Tanzania. - Karstenia 35 (suppl.):1-92.

Heim, R. 1938: Diagnoses latines d'espèces et variétés nouvelles de Lactario-Russulés du domaine oriental de Madagascar. - Candollea 7:374-393.

Heim, R. 1955: Les Lactaires d'Afrique intertropicale. Bull. Jard. Bot. État 25:1-91.

Korhonen, M. 1984: Suomen rouskut. (Summary: Lactarius species of Finland) - 223 pp. Otava, Helsinki.

Morris, B. 1990: An annotated check-list of the macrofungi of Malawi. - Kirkia 13:323-390.

Munyanziza, E. 1994: Miombo trees and mycorrhizae. Ecological strategies, a bases for afforestation. Ph.D. dissertation, Univ. Wageningen (Netherlands), 192 pp.
Parent, G. \& Thoen, D. 1977: Food value of edible mushrooms from Upper-Shaba Region. - Econ. Bot. 31:436-445.

Pegler, D. 1977: A preliminary agaric flora of East Africa. - Kew Bull. Add. Ser. 6:1-615.

Pegler, D. 1982: Agaricoid and boletoid fungi (Basidiomycota) from Malawi and Zambia. - Kew Bull. 37:255-271.

Pegler, D. \& Fiard, J.P. 1979: Taxonomy and ecology of Lactarius (Agaricales) in the Lesser Antilles. - Kew Bull. 33:601-628.

Pegler, D. \& Piearce, G.D. 1980: The edible mushrooms of Zambia. - Kew Bull. 35:475-491.

Piearce, G.D. 1981a: An introduction to Zambia's wild mushrooms and how to use them. -28 pp. Forest Dept., Ndola.

Piearce, G.D. 1981b: Zambian mushrooms, customs and folklore. - Bull. British Mycol. Soc. 15:139-142.

Ryvarden, L., Piearce, G.D. \& Masuka, A.J. 1994: An introduction to the larger fungi of South Central Africa. - 200 pp. Baobab Books, Harare.

Saarimäki, T., Härkönen, M. \& Mwasumbi, L. 1994: Tanzanian mushrooms and their uses 3. Termitomyces singidensis, sp. nov. - Karstenia 34:13-20.

Singer, R. 1986: The Agaricales in Modern Taxonomy. - 903 pp. Koeltz Scientific Books, Koenigstein.

Verbeken, A. 1995a: Further notes on Lactarius edulis Verbeken \& Buyck. - Russulales News 3:18-23.

Verbeken, A. 1995b: Studies in tropical African Lactarius species. 1. Lactarius gymnocarpus R. Heim ex Singer and allied species. - Mycotaxon 55:515-542.

Verbeken, A. 1996a: Studies in tropical African Lactarius species 3. Lactarius melanogalus R. Heim and related species. - Persoonia 16:209-223.

Verbeken, A. 1996b: New taxa of Lactarius (Russulaceae) in tropical Africa. - Bull. Jard. Bot. Nat. Belg. 65:197-213.

Verbeken, A. 1996c: Biodiversity of the genus Lactarius Pers. in tropical Africa. - Ph.D. dissertation, Rijksuniversiteit Gent, Part 1: 1-342, Part 2: 1-269 + 29 maps (mimeo).

Verbeken, A. 1996d: Studies in tropical African Lactarius species. 4. Species described by $\mathrm{P}$. Hennings and M. Beeli. - Edinb. J. Bot. 53:49-79.

van der Westhuizen, G.C.A. \& Eicker, A. 1994: Mushrooms of Southern Africa. - 207 pp. Struik Pub., Cape Town.

White, F. 1983: The vegetation of Africa. - Unesco Nat. Resources Res. 20:1-356.

Williamson, J. 1975: Useful plants of Malawi. - 336 pp. University of Malawi, Zomba.

Received on 3 July 1997 